Lacey, J.H., Leng, M.J., Vane, C.H., Radbourne, A.D., Yang, H., Ryves, D.B., 2018. Assessing human impact on Rostherne Mere, UK, using the geochemistry of organic matter. Anthropocene, 21, 52-65.

This is the author's version of a work that was accepted for publication in Anthropocene.

Changes may have been made to this work since it was submitted for publication. This version was submitted to Anthropocene following peer review.

The final version of this paper has been published in Anthropocene, Volume 21, March 2018.

The final publication is available from https://doi.org/10.1016/j.ancene.2018.02.002.

(c) 2018. This manuscript version is made available under the CC-BY-NC-ND 4.0 license http://creativecommons.org/licenses/by-nc-nd/4.0/ 


\title{
Assessing human impact on Rostherne Mere, UK, using the geochemistry of organic matter
}

\author{
Jack H. Lacey ${ }^{a^{*}}$, Melanie J. Leng ${ }^{\text {a,b }}$, Christopher H. Vane ${ }^{\text {c }}$, Alan D. Radbourne ${ }^{\text {d }}$, \\ Handong Yang e, David B. Ryves ${ }^{d}$
}

${ }^{a}$ NERC Isotope Geosciences Facilities, British Geological Survey, Keyworth, Nottingham, UK

${ }^{\mathrm{b}}$ Centre for Environmental Geochemistry, School of Biosciences, Sutton Bonington Campus, University of Nottingham, Loughborough, UK

${ }^{\mathrm{c}}$ British Geological Survey, Keyworth, Nottingham, UK

${ }^{\mathrm{d}}$ Centre for Ecological and Hydrological Science (CHES), Department of Geography, Loughborough University, Loughborough, UK

${ }^{\mathrm{e}}$ Environmental Change Research Centre, University College London, London, UK

*corresponding author (jackl@bgs.ac.uk)

\begin{abstract}
This study investigates recent changes in the geochemistry of organic material from a hypereutrophic lake (Rostherne Mere, United Kingdom) using the geochemical and molecular composition of radiometrically dated sediment cores. Modern samples suggest that recent sedimentation is dominated by algal production; however, a minor component of allochthonous organic material is present. Sediment cores reveal that absolute proxy values and the magnitude of observed changes are broadly homogenous across the lake basin. A transition to environmental conditions favouring enhanced algal productivity in recent sediments is suggested by higher total organic carbon (TOC) and lower carbon to nitrogen ratio $(\mathrm{C} / \mathrm{N})$, carbon isotope composition of organic matter $\left(\delta^{13} \mathrm{C}_{\text {org }}\right)$, and average $n$-alkane chain length. A strong covariance between TOC and Rock-Eval Hydrogen Index implies this transition is driven by an increasing algal contribution rather than being a response to variations in the source of organic matter. Decadal trends and abrupt shifts in organic geochemical proxies are suggested to be directly related to changes in external anthropogenic nutrient loading following the construction and decommissioning of sewage treatment plants. The development of hypereutrophic conditions likely occurred in stages, where rapid transitions are associated with the commencement of sewage effluent input in the 1930s, population increases in the 1980s, and a dramatic reduction in external nutrient loads in the 1990s. Recovery of the lake ecosystem is limited by internal nutrient recycling, and organic proxies indicate that the geochemistry of sediments has remained relatively constant since effluent diversion. This study highlights the utility of organic geochemical parameters in tracing recent eutrophication processes in lakes to provide evidence for the timing and scale of anthropogenic environmental change.
\end{abstract}

Keywords: Lake sediment, Organic matter, Rock-Eval pyrolysis, Biomarkers, Eutrophication, Anthropogenic impact 


\section{Introduction}

Organic matter is a key biogeochemical component of lake sediment, and comprises a complex mixture of material that originates from organisms living within the lake and in its surrounding catchment. In many productive lakes, the autochthonous detritus of phytoplankton is the dominant source of organic material to sediments (Cohen, 2003), although the contribution from macrophytes and allochthonous organic matter pools, such as terrestrial plant materials and soils, can also be important (Meyers, 1997). The geochemical composition of lacustrine organic matter can be used to distinguish the source of material preserved in lake sediments and to identify alteration pathways, therefore providing information on environmental change over the history of a lake (Meyers and Ishiwatari, 1993). Many studies use established bulk geochemical proxies, including the carbon isotope composition of organic matter $\left(\delta^{13} \mathrm{C}_{\mathrm{org}}\right)$ and carbon to nitrogen ratio $(\mathrm{C} / \mathrm{N})$, for palaeoenvironmental reconstructions (Meyers and Teranes, 2001), but these proxies cannot fully discriminate between different organic pools (Holtvoeth et al., 2016). Therefore, a combination of other techniques is needed.

Rock-Eval pyrolysis is a screening technique typically associated with determining the hydrocarbon potential of petroleum source rocks (Espitalie et al., 1977); however, the technique has more recently been applied in palaeoenvironmental investigations to examine the organic composition of sediments from soils, wetlands, and lakes (Zocatelli et al., 2012; Khan et al., 2013; Sebag et al., 2013; Lacey et al., 2015; Newell et al., 2016). These studies highlight how Rock-Eval parameters can be used to assess the relative contributions from different sources of organic matter in sediments, and they provide evidence on the geochemical quality and degradation history of organic material. In addition, biomarkers can trace specific compounds to an individual organism, group, or process (Peters et al., 2005), enabling the recovery of detailed palaeoenvironmental information (Castañeda and Schouten, 2011). While the geochemical analysis of bulk sediment is useful for detailing general trends, biomarkers provide specific information on production, delivery, and preservation of organic sediment components (Meyers, 1997). For example, homologues of saturated, long, straightchained hydrocarbons, the normal alkanes ( $n$-alkanes), can differentiate sources of organic matter. Short-chain $n$-alkanes are typical of aquatic algae $\left(n \mathrm{C}_{15-21}\right)$, a large component of which are dominated by the $n \mathrm{C}_{17}$ alkane (Clark and Blumer, 1971; Cranwell et al., 1987). Mid-length chains $\left(n \mathrm{C}_{23-25}\right)$ are associated with submerged aquatic macrophytes, and longer chains $\left(n \mathrm{C}_{27-35}\right)$ are a dominant component of higher plants and emergent macrophytes (Eglinton and Hamilton, 1967; Ficken et al., 2000).

Organic matter from both aquatic and terrestrial sources may also be subject to mineralisation and degradation, and consequently, it is important for palaeoenvironmental reconstructions to identify the extent of alteration (Meyers and Teranes, 2001). The concentration of hydrogen in hydrocarbons is influenced by the redox conditions of the depositional environment because hydrocarbons are commonly volatile in the presence of oxygen (Cohen, 2003). Therefore, Rock-Eval proxies can provide evidence on the geochemical quality and degradation history of organic matter.

Recent eutrophication of lakes is common due to the increased input of phosphorus $(\mathrm{P})$ and nitrogen $(\mathrm{N})$ from effluent, agricultural runoff, and other anthropogenic nutrient sources. Eutrophication can lead to a loss of biodiversity and also directly affects the health of humans 
and animals through declining water quality (Krivtsov et al., 2001; Moss et al., 2005). One such eutrophic lake is Rostherne Mere in the United Kingdom (UK). Over much of the $20^{\text {th }}$ century (1935-1991), the lake received effluent from a local sewage treatment works in addition to nutrient-rich runoff from surrounding farmland (Carvalho et al., 1995). The site is of international importance (designated as a National Nature Reserve, Ramsar site, and Site of Special Scientific Interest) and has a long-standing history of scientific monitoring since 1912 (Pearsall, 1923; Reynolds and Bellinger, 1992). In addition, Rostherne Mere has a welldocumented history of anthropogenic catchment disturbance, making it a unique site to investigate human impact on the lacustrine environment through the organic geochemistry of lake sediments. Previous geochemical work on surface sediments and a $30 \mathrm{~cm}$ core collected from the deepest part of the lake suggested a high contribution of algal material to the most recent sediments (Brooks et al., 1976; Gaskell and Eglinton, 1976; Cardoso et al., 1983), although no chronological work was carried out on the core. Analysis of molecular and isotope composition of a 35-cm sediment core taken from the lake in 1993(Prartono and Wolff, 1998) also indicated a strong allochthonous contribution in surficial sediments. Similar to previous work, no dating was carried out on the core, and end-member materials were not defined.

We present a new multi-proxy organic geochemical record from Rostherne Mere that combines total organic carbon (TOC) and total nitrogen (TN) concentrations (from which we calculate $\mathrm{C} / \mathrm{N}$ ), $\delta^{13} \mathrm{C}_{\text {org }}$, Rock-Eval parameters, and biomarkers ( $n$-alkanes) on radiometrically dated sediment cores. This study also uses trap sediments, fresh vegetation, and soil samples to identify the main constituents of modern sedimentary organic matter and improve end-member characterisation, as well as evaluate the role of degradation in both anoxic and oxic environments through litter bag experiments. Our main aim was to assess quantitatively the geochemistry of recent sedimentary organic matter to provide a calibration of modern materials and to identify the primary drivers and timing of environmental change at Rostherne Mere. This assessment supports characterisation of the transition to hypereutrophic conditions and the effectiveness of remedial actions at the lake. We hypothesise that major shifts in the geochemical composition of sediments will occur contemporaneously with the introduction and cessation of sewage effluent input as a result of organic matter productivity changes due to variations in external nutrient loading. Overall, this work seeks to demonstrate the efficacy of using organic geochemistry to investigate the impact of human activity on lacustrine environments.

\section{Study site}

Rostherne Mere $\left(53^{\circ} 20^{\prime} \mathrm{N}, 2^{\circ} 24^{\prime} \mathrm{W}\right)$ is the most northerly of a sequence of three meres, together with Mere Mere and Little Mere, located $17 \mathrm{~km}$ southwest of Manchester in the Shropshire-Cheshire plain, UK (Figure 1). The elongate lake basin most likely formed as a kettle hole, which deepened due to gradual subsidence caused by the dissolution of underlying salt-bearing strata following ice sheet retreat at the end of the last glacial period (Banks, 1970; Reynolds, 1979). The lake has a maximum depth of $31 \mathrm{~m}$ and an average depth of $14 \mathrm{~m}$ and covers an area of approximately $0.5 \mathrm{~km}^{2}$, making it one of the largest and deepest of the Shropshire-Cheshire meres (Reynolds, 1979). The large lake volume of $6.6 \times 10^{6} \mathrm{~m}^{3}$ (Woof and Wall, 1984) produces a long water residence time of 1.5-2.7 years 
(Carvalho, 1993; Moss et al., 2005), although recent high resolution monitoring suggests a residence time of closer to ca. 0.8 years (Radbourne, 2018). The majority of water inflow to Rostherne Mere is from Rostherne Brook ( 75\%), which enters at the southwest margin of the lake and drains $7 \mathrm{~km}^{2}$ of the $9-\mathrm{km}^{2}$ catchment (Carvalho et al., 1995). The remaining water input is divided between contributions from small springs and transitory drainage ditches, groundwater, and direct rainfall (Carvalho, 1993; Carvalho et al., 1995). Water output comprises evaporation from the lake surface during the summer months and river outflow through Blackburn's Brook at the southeast margin. The lake is monomictic, and thermal stratification typically arises between April and November, causing anoxia in the hypolimnion. Dissolved oxygen stratification takes place from early Summer, and peak deoxygenation occurs during late September to early October and can extend to the base of the thermocline around 12-m water depth (Davison and Woof, 1984; Scott, 2014). The stratification regime is enhanced by eutrophication, which has increased over the $20^{\text {th }}$ century due to anthropogenic nutrient enrichment sourced from increased agricultural runoff and upstream sewage effluent input (Carvalho et al., 1995; Krivtsov et al., 2001). Two sewage treatment plants have discharged effluent into the lake since their construction in 1935, dominating the external nutrient load sourced from Rostherne Brook. After the sewage flow was diverted from the catchment in 1991, external nutrient loads decreased by up to $75 \%$ (Moss et al., 1997). Conversely, internal nutrient variation was relatively consistent between years, steadily decreasing until 2002 (Moss et al., 2005), and has since stabilised, showing only minor oscillations (Radbourne, 2018). High concentrations of $\mathrm{P}$ and $\mathrm{N}$ accumulate in the hypolimnion during the spring-autumn period of stratification and anoxia and are then released and transferred to the epilimnion following overturn in late November (Carvalho et al., 1995; Scott, 2014). The substantial degree of internal nutrient loading within the basin results in high levels of primary productivity and the development of algal blooms. Summer months are dominated by cyanobacteria and cryptophytes, principally consisting of Anabaena spp., Aphanizomenon flos-aquae, and Cryptommonas. Planktonic diatom blooms, mainly comprising Asterionella formosa, Aulacoseira granulata, and smaller centrics (e.g. Stephanodiscus and Cyclostephanos spp.), are typical of spring and autumn months (Carvalho, 1993; Moss et al., 2005). Submerged aquatic plant species diversity today is very low, and Callitriche hermaphroditica dominates in littoral areas less than $1 \mathrm{~m}$ deep. Lake margins are dominated by a narrow band of Phragmites australis with some Typha angustifolia, behind which is Salix scrub and alder carr (Alnus glutinosa) with areas of relatively species-rich wetland vegetation (Natural England, 2012).

\section{Materials and methods}

\subsection{Core recovery and sampling}

A 27-cm-long sediment core (RM-S1) was recovered from the northwestern part of the lake in June 2014 at a water depth of 4.9 m (oxic zone; Figure 1) using a HON-Kajak gravity corer (Renberg, 1991). The RM-S1 core was extruded in the field at 1-cm intervals. A further 51-cm-long core (RM-D4) was retrieved from the central pelagic area in September 2014 at a water depth of $30.8 \mathrm{~m}$ (anoxic zone; Figure 1). The coring tube was packed with a foam block, wrapped in polythene film, and transported to the British Geological Survey (BGS). 
The tube was split, the core halves were frozen, and the partially thawed working half was sectioned at $1-\mathrm{cm}$ intervals and then freeze-dried.

To enable the examination of the geochemical composition of autochthonous and floating allochthonous organic matter, we installed open-tube sediment traps in the central pelagic area of the lake in April 2014 ( 30-m water depth). A shallow trap was set at $8 \mathrm{~m}$ below the lake surface, and a deeper trap was set at $22.5 \mathrm{~m}$ below the lake surface. The open traps consist of four plastic tubes set in a cross shape that have a trapping ratio of $6.25(450-\mathrm{mm}$ length, 72-mm internal diameter). The traps were recovered and emptied in June 2014 and reset at the same locations and depths. A second collection was conducted in September 2014. Following each collection, the trap samples from respective sampling depths were amalgamated in polypropylene bottles.

To investigate the major allochthonous sources of organic matter to Rostherne Mere, we collected surface soil samples from a grassland meadow, a woodland, and the channel of Rostherne Brook using a spade. In addition, we collected submerged and emergent macrophytes from the shoreline of the mere, including Phragmites, Typha, and the submerged macrophyte Callitriche. The Phragmites and Typha samples were divided into two groups; the first included the stems and leaves, and the second comprised the roots. The five plant samples (Phragmites root/stem, Typha root/stem, and Callitriche) were then each sub-divided into three aliquots. To examine the possible effects degradation may have on the geochemistry of the fresh vegetation, two of the three aliquots of each sample were sealed within individual $125-\mu \mathrm{m}$ mesh bags using cable ties. One group of five aliquots was submerged in the central pelagic area at a water depth of $26.5 \mathrm{~m}$ within the deoxygenated zone, and the second group of five aliquots was submerged in the shallow oxic zone in the northwestern part of the lake at a water depth of $5.2 \mathrm{~m}$. Both groups were left in the water column at their respective depths for three months between April and September 2014 and then recovered and transferred to polythene bags. The trap sediment, vegetation, and soil samples were freeze-dried and freezer milled prior to analysis.

\subsection{Chronology}

ORTEC High-Purity Germanium (HPGe) GWL series, well-type coaxial, low background intrinsic germanium detectors at the Environmental Radiometric Facility, University College London, analysed the sediment samples from cores RM-D4 and RM-S1 for lead-210 $\left({ }^{210} \mathrm{~Pb}\right)$, radium-226 $\left({ }^{226} \mathrm{Ra}\right)$, cesium-137 $\left({ }^{137} \mathrm{Cs}\right)$, and americium-241 $\left({ }^{241} \mathrm{Am}\right)$ by direct gamma assay (as described by Yang and Turner, 2013). ${ }^{210} \mathrm{~Pb}$ was determined by means of its gamma emissions at $46.5 \mathrm{keV}$. Samples were stored for three weeks in sealed containers to allow for radioactive equilibration, and ${ }^{226} \mathrm{Ra}$ was then measured by the $295-\mathrm{keV}$ and $352-\mathrm{keV}$ gamma rays emitted by its daughter isotope lead-214 $\left({ }^{214} \mathrm{~Pb}\right) .{ }^{137} \mathrm{Cs}$ and ${ }^{241} \mathrm{Am}$ were determined by their emissions at $662 \mathrm{keV}$ and $59.5 \mathrm{keV}$. Corrections were applied to account for the effect of self-absorption of low-energy gamma rays within the sample (Appleby et al., 1992).

\subsection{Isotope analysis of organic matter and $\mathrm{C} / \mathrm{N}$}

Samples were analysed for TOC, TN, and $\delta^{13} \mathrm{C}_{\text {org }}$ at the BGS. For the soils and lake sediments, any carbonate present was removed prior to analysis by immersing in 5\% hydrochloric acid for 24 hours and then rinsed in deionised water to neutral $\mathrm{pH}$, dried at 40 
${ }^{\circ} \mathrm{C}$, and homogenised in agate. An on-line system comprising a Costech ECS4010 elemental analyser (TOC and TN) and a VG Triple-Trap and Optima dual-inlet mass spectrometer $\left(\delta^{13} \mathrm{C}_{\text {org }}\right)$ analysed the prepared samples in tin capsules. $\delta^{13} \mathrm{C}_{\text {org }}$ values were calibrated to the Vienna Pee Dee Belemnite (V-PDB) scale using within-run laboratory standards (BROC2 and SOILB) calibrated against NBS 19 and NBS 22 international standards. Analytical reproducibility $(1 \sigma)$ for the within-run laboratory standards was $<0.05 \%$ for $\delta^{13} \mathrm{C}_{\text {org }}$ and $<0.5 \%$ for TOC and TN. C/N is given as the weight ratio.

\subsection{Rock-Eval pyrolysis}

A Rock-Eval 6 analyser (configured in standard mode - pyrolysis and oxidation as a sequential process) at the BGS analysed samples using a technique previously employed for lake sediments and peats (Lacey et al., 2015; Newell et al., 2016). The performance of the instrument was assessed by comparison to the accepted values of Institute Français du Pétrole standards (IFP 160000, S/N1 5-081840). Rock-Eval parameters were determined as the amount of hydrocarbons previously generated and distilled upon heating to $300{ }^{\circ} \mathrm{C}(\mathrm{S} 1)$, hydrocarbons generated through thermal cracking of bound organic matter (S2), carbon dioxide $\left(\mathrm{CO}_{2}\right)$ released during pyrolysis ( $\left.\mathrm{S} 3\right)$, TOC (sum of pyrolised and residual carbon), and mineral carbon (MinC; e.g. calcium carbonate). The hydrocarbons generated as a proportion of the total organic matter, Hydrogen Index (HI), is calculated from $\mathrm{HI}=\mathrm{S} 2 * 100 / \mathrm{TOC}$, and the amount of oxygen with respect to total organic matter, Oxygen Index (OI), is calculated from $\mathrm{OI}=\mathrm{S} 3 * 100 / \mathrm{TOC}$.

\section{5 n-Alkane analysis}

Freeze-dried samples from cores RM-S1 and RM-D4, trap sediment, vegetation, and soils were analysed for $n$-alkanes at BGS using the technique described by Newell et al. (2016). The estimated ratio of terrigenous to aquatic $n$-alkanes (TAR; Bourbonniere and Meyers, 1996) was calculated using the quantified peak areas TAR $=\left(n \mathrm{C}_{27}+n \mathrm{C}_{29}+n \mathrm{C}_{31}\right) /\left(n \mathrm{C}_{15}+\right.$ $\left.n \mathrm{C}_{17}+n \mathrm{C}_{19}\right)$. To further characterise the distribution of $n$-alkanes, we determined the weighted average $n$-alkane carbon chain length (ACL; Bush and McInerney, 2013), where $\mathrm{C}_{\mathrm{n}}$ is the $n$-alkane concentration and $n$ the number of carbon atoms, using $A C L=\Sigma\left(C_{n} \times n\right) /$ $\Sigma\left(C_{n}\right)$. We calculated the relative contribution to lake sediments from submerged or floating macrophytes in comparison to emergent and terrestrial plants $\left(\mathrm{P}_{\mathrm{aq}}\right.$; Ficken et al., 2000) using $\mathrm{P}_{\mathrm{aq}}=\left(n \mathrm{C}_{23}+n \mathrm{C}_{25}\right) /\left(n \mathrm{C}_{23}+n \mathrm{C}_{25}+n \mathrm{C}_{29}+n \mathrm{C}_{31}\right)$.

\section{Results}

\subsection{Chronology}

For core RM-S1, total ${ }^{210} \mathrm{~Pb}$ activity reached equilibrium with supported ${ }^{210} \mathrm{~Pb}$ activity at 23 $\mathrm{cm}$ in depth (Figure 2). The maximum level of unsupported ${ }^{210} \mathrm{~Pb}$ is found below the surface at $3.5 \mathrm{~cm}$, suggesting an increase in sedimentation rates in recent years. A transition to lower levels of unsupported ${ }^{210} \mathrm{~Pb}$ between 15 and $18 \mathrm{~cm}$ implies high sedimentation rates and implies that sediment slumping, likely to have been instantaneous, may have occurred. A well-resolved ${ }^{137} \mathrm{Cs}$ peak at $12.5 \mathrm{~cm}$ (Figure 2) most probably reflects the fallout from atmospheric testing of nuclear weapons in 1963 . A simple constant rate of ${ }^{210} \mathrm{~Pb}$ supply 
(CRS) model was used for dating, and the ${ }^{137} \mathrm{Cs}$ peak at $12.5 \mathrm{~cm}$, along with a concomitant peak in ${ }^{241} \mathrm{Am}$ (Figure 2), corrected the final ${ }^{210} \mathrm{~Pb}$ chronology for core RM-S1, such that 12.5 cm core depth equates to 1963.

In core $\mathrm{RM}-\mathrm{D} 4$, total ${ }^{210} \mathrm{~Pb}$ activity reached equilibrium with supported ${ }^{210} \mathrm{~Pb}$ activity at 49 $\mathrm{cm}$ in depth (Figure 2). A relatively uniform sedimentation rate across the upper $35 \mathrm{~cm}$ of the core is suggested by a balanced exponential decline in unsupported ${ }^{210} \mathrm{~Pb}$ activity and increased sedimentation rates at around $38 \mathrm{~cm}$. The well-resolved ${ }^{137} \mathrm{Cs}$ peak at $37.5 \mathrm{~cm}$ most likely is contemporaneous with the peak observed in core RM-S1 at $12.5 \mathrm{~cm}$ and reflects the maximum fallout from atmospheric nuclear weapons testing in 1963, which is supported by a concomitant excursion in ${ }^{241} \mathrm{Am}$ (Figure 2). The ${ }^{137} \mathrm{Cs}$ and ${ }^{241} \mathrm{Am}$ tie point of $37.5 \mathrm{~cm}$ equating to 1963 corrected the final ${ }^{210} \mathrm{~Pb}$ chronology for core RM-D4.

\subsection{Trap sediments, soils, and vegetation samples}

Results for trap sediments, soils, and vegetation samples are given in Table 1 and Figure 3. The trap collection from June shows high MinC (6\%) and TOC (10\%) and low C/N (7) and $\delta^{13} \mathrm{C}_{\text {org }}(-31 \%)$. TOC, $\mathrm{C} / \mathrm{N}$, and $\delta^{13} \mathrm{C}_{\text {org }}$ increase in the September trap $(19 \%, 8$, and $-28 \%$, respectively), and MinC decreases to $3 \%$. Rock-Eval parameter $\mathrm{HI}$ is broadly consistent between the two collection periods (390-400), although it decreases to 370 in the deep water June trap, coincident with higher OI (219). OI is lower ( 164) in September. ACL and TAR remain consistent between June and September collections. All of the trap sediments show a narrow $n$-alkane composition dominated by a strong maximum at $n \mathrm{C}_{17}$ and only have a minor contribution from longer-chained $n$-alkanes (Figure 3). Total alkane concentrations are higher for the September trap sediments (average $=\sim 104 \mu \mathrm{g} / \mathrm{g}$ ) compared to the trap sediments collected in June (average $\sim 60 \mu \mathrm{g} / \mathrm{g}$ ).

All three soil samples show very low MinC (<1\%) and relatively low TOC ( $3-6 \%)$; however, $\mathrm{C} / \mathrm{N}$ is much higher for woodland soil $(\mathrm{C} / \mathrm{N} \sim 35)$ than for inflow and grassland soils (C/N 12; Table 1). Woodland and inflow soils have similar HI and OI ( 204 and 237, respectively), with grassland soil showing marginally higher values for both $\mathrm{HI}$ and OI (266 and 260, respectively). Soil $\delta^{13} \mathrm{C}_{\text {org }}$ ranges between -27.8 and $-29.5 \%$ (Table 1). Ratios of $n$ alkanes are relatively consistent between the different soil samples, and ACL ( 27.6) and TAR ( 32.2) are high. Total $n$-alkane concentrations for soils are comparatively low (between $\sim 9$ and $20 \mu \mathrm{g} / \mathrm{g}$ ), and carbon chain length maxima are at $n \mathrm{C}_{27}, n \mathrm{C}_{29}$, and $n \mathrm{C}_{31}$ for woodland, inflow, and grassland soils, respectively (Figure 3).

Fresh samples of the dominant vegetation collected around and within the lake (Phragmites, Typha, and Callitriche) show low MinC and high TOC, HI, and OI (Table 1). The submerged aquatic macrophyte Callitriche has lower $\mathrm{C} / \mathrm{N}(12.3)$ and higher $\delta^{13} \mathrm{C}_{\text {org }}(-24.5 \%)$ compared to Phragmites and Typha root and stem samples $\left(\mathrm{C} / \mathrm{N}>30, \delta{ }^{13} \mathrm{C}_{\mathrm{org}} \sim-28.0 \%\right.$; $\mathrm{C} / \mathrm{N}$ could not be calculated for Phragmites and Typha roots due to very low N). Fresh Phragmites and Typha root samples and Callitriche have an ACL of $\sim 25$, whereas the stem samples of Phragmites and Typha show moderately higher ACL values between 26 and 28 . The fresh vegetation samples show a broad $n$-alkane composition (Figure 3 ), typically having maxima above $n \mathrm{C}_{25}$, where total $n$-alkane concentrations range from $\sim 10 \mu \mathrm{g} / \mathrm{g}$ (Phragmites root) up to $\sim 486 \mu \mathrm{g} / \mathrm{g}$ (Typha stem). The $n$-alkane composition of Callitriche shows a bimodal distribution with carbon chain length maxima at both $n \mathrm{C}_{23}$ and $n \mathrm{C}_{29}$ (Figure 3). 
Vegetation samples that were submerged in the lake and exposed to anoxic and oxic conditions typically have lower TOC when compared to their fresh vegetation equivalent, although Phragmites and Typha stems only display a minor change in TOC (Table 1). A $-4 \%$ shift in $\delta^{13} \mathrm{C}_{\text {org }}$ of Callitriche is observed between fresh and degraded samples, whereas both root and stems of Phragmites and Typha have more consistent values. Conversely, HI remains unchanged in Callitriche between fresh and degraded samples, in contrast to Typha and Phragmites, which show a major increase in $\mathrm{HI}$ for those samples exposed to oxic conditions and a lesser increase for anoxic conditions. OI decreases substantially in all degraded vegetation samples. Total $n$-alkane concentrations for degraded Typha and Phragmites samples are generally higher than fresh counterparts, whereas degraded Callitriche has a lower $n$-alkane concentration than fresh material (Figure 3). The overall $n$ alkane distribution of degraded Typha and Phragmites is consistent with the observed pattern in fresh samples.Callitriche, however, shows a shift to an $n \mathrm{C}_{27}$-dominated assemblage under oxic conditions and is $n \mathrm{C}_{27}-n \mathrm{C}_{29}$-dominated under anoxic conditions, losing a component of long- and short-chained homologues.

\subsection{Sediment cores}

Bulk organic geochemical data and $n$-alkane-based ratios for core RM-S1 are shown in Figure 4, and averaged data are provided in Table 1. From the Rock-Eval data, MinC ranges from 1 to $3 \%$ and is lowest at the base of the core $(<1 \%)$, showing a trend towards higher values up to the top of the core. TOC is stable around $11 \%$ up to $17 \mathrm{~cm}$, after which values increase between 17 and $7 \mathrm{~cm}$ and then show fluctuations around a mean of $16 \%$ in the uppermost sediments. There is a higher degree of variability in $\mathrm{C} / \mathrm{N}$ in the lower core, where values are between 14 and 16 . Above $17 \mathrm{~cm}, \mathrm{C} / \mathrm{N}$ is more stable, showing a trend to lower values and decreasing to a $\mathrm{C} / \mathrm{N}$ of 10 at the very top of the core. As with TOC, $\delta^{13} \mathrm{C}_{\text {org }}$ has consistent values of around $-27 \%$ o between the base of the core and $19 \mathrm{~cm}$. The $\delta^{13} \mathrm{C}_{\text {org }}$ decreases between $17 \mathrm{~cm}$ and the top of the core, and the rate of decline increases between 10 and $5 \mathrm{~cm}$ where $\delta^{13} \mathrm{C}_{\text {org }}$ values are approximately $-29 \%$. A progressive increase in HI from a value of 232 up to 296 is observed between the base of the core and $10 \mathrm{~cm}$, followed by a transition to lower $\mathrm{HI}$ around $5 \mathrm{~cm}$ and then a subsequent increase to values around 300 at the top of the core. OI shows an opposing trend to $\mathrm{HI}$ in the lowermost core where values decrease from 166 to 145 between 27 and $16 \mathrm{~cm}$. OI shows a consistent increase through the rest of the core to a value of 204 in the most recent sediments. The $n$-alkane-based ratios ACL and TAR are both high in the lower core, around 28 and 12, respectively, and show a shift to lower values of around 25 and 3, respectively, in the upper core. The $\mathrm{P}_{\mathrm{aq}}$ ratio has an opposing trend, having lower values around 0.2 at the bottom of the core that transition to higher values around 0.5 in the upper core.

Bulk geochemical data and $n$-alkane-based ratios for core RM-D4 are given in Figure 5, and averaged data are provided in Table 1. MinC progresses from lower to higher values throughout the core, ranging between approximately 1 and 4\%. TOC has variable but increasing values between 5 and $13 \%$ at the bottom of the sequence up to around $30 \mathrm{~cm}$. After $30 \mathrm{~cm}$, values are more consistent between 11 and $13 \%$ until the upper few $\mathrm{cm}$ of sediment where an increase to $\sim 15 \%$ TOC is observed. C/N shows a broad decline to lower values throughout the core, and is between values of 14 at the very base of the core and 9 at the top of the core. As with $\mathrm{C} / \mathrm{N}, \delta^{13} \mathrm{C}_{\text {org }}$ decreases throughout the core from $-27 \%$ in basal 
sediments to $-30 \%$ at the top of the core with a pronounced shift to lower $\delta^{13} \mathrm{C}_{\text {org }}$ around 13 $\mathrm{cm}$ core depth. An increase in HI from roughly 180 to 280 is observed through the bottom 20 $\mathrm{cm}$ of the core, followed by relatively stable values of around 275 between 31 and $3 \mathrm{~cm}$ and an increase to 333 in surface sediments. From the base of the core to $24 \mathrm{~cm}$, OI shows a decreasing trend from a maximum value of 212 down to a minimum value of 156 . The decrease is followed by a shift to higher and more stable values of around 187 up to $5 \mathrm{~cm}$, after which OI decreases to around 172 in the uppermost sediments. In the lower core (51 to $17 \mathrm{~cm})$, the $n$-alkane ratios ACL and TAR are both high ( 27 and 7, respectively) and show a change to lower values in the upper core ( $\sim 25$ and 2 , respectively). The ratio $\mathrm{P}_{\mathrm{aq}}$ shows little overall variation through core RM-D4, with values ranging between 0.18 and 0.24.

\section{Discussion}

\subsection{Characterisation of modern sediments and post-depositional processes}

Substantial, long-term shifts across bulk and molecular organic geochemical proxies are evident in sediment cores RM-D4 and RM-S1 from Rostherne Mere (Figures 4 and 5). To better understand the primary driving influences and historical context of the observed changes, it is important to be able to determine the mechanisms underlying proxy variations. This determination can be made by examining the organic matter that contributes to the lake sediments through end-member characterisation and evaluating the potential for postdepositional changes.

Previous studies on the composition of organic matter in Rostherne Mere suggested the predominance of organic material transferred to recent sediments comprises autochthonous components (Gaskell and Eglinton, 1976; Cardoso et al., 1983). This conclusion is confirmed by the uniform $n$-alkane maxima at $n \mathrm{C}_{17}$ observed across sediment trap data (Figure 3 ), suggesting a principal abundance of algal material (Clark and Blumer, 1971; Cranwell et al., 1987). Diatom blooms between March and June can account for over $90 \%$ of annual diatom growth (Livingstone and Reynolds, 1981) and have been dominated in recent years by the species Asterionella formosa and Aulacoseira granulata (Reynolds, 1978; Moss et al., 2005; Radbourne, 2018). In summer and autumn months, the most prevalent taxa of phytoplankton are the cyanobacteria Aphanizomenon flos-aquae and Anabaena spp., as well as the cryptophyte Cryptomonas (Moss et al., 2005). Trap sediments collected in June and September therefore represent end-member values for the major phytoplankton blooms in Rostherne Mere, where the diatom-dominated assemblage (April-June) has $\delta^{13} \mathrm{C}_{\text {org }}$ of $-31 \%$ and the cyanobacteria-cryptophyte assemblage (June-September) has $\delta^{13} \mathrm{C}_{\text {org }}$ of $-28 \%$. Both assemblages have $\mathrm{C} / \mathrm{N}$ typical of aquatic organic matter of between $\sim 7$ and 8 (Table 1). The difference in $\delta^{13} \mathrm{C}_{\text {org }}$ of $+3 \%$ o between the two collection periods is most likely driven by the removal of ${ }^{12} \mathrm{C}$ from the dissolved inorganic carbon pool by productivity-driven export to sediments during summer months. High HI values of $\sim 400$ for the shallow traps is also indicative of a kerogen-rich algal source of organic material and is consistent with the deeper trap sediments collected through June-September. Lower HI values ( 370$)$ from the deeper trap during the collection between April and June, which, alongside a higher OI, suggest that greater degradation occurs within the water column upon sinking and may be related to the onset of stratification and development of anoxia. In the months before anoxia takes hold throughout the hypolimnion and extends to the thermocline, reaching a maximum 
in late September (Davison and Woof, 1984), sinking organic matter derived from algal blooms will be exposed to a more oxygenated water column; hence, there is a greater potential for oxidation. The trap sediment data therefore imply that degradation in the water column may lead to lower HI and higher OI values of sinking organic matter when compared to fresh in situ material, as described by Meyers and Lallier-Verges (1999). Overall interpretations of material provenance (i.e. terrestrial vs. aquatic sources), however, are still valid.

A comparison of trap sediments with the uppermost samples of core RM-D4 (rather than core RM-S1 due to coring location and month of recovery) illustrates the transition and incorporation of fresh organic material from the water column into the sedimentary record. Because mean annual sedimentation rates are $0.7 \mathrm{~cm}_{\text {year }}{ }^{-1}$ (based on the ${ }^{210} \mathrm{~Pb}$ chronology of core RM-D4), the uppermost core sediments from the deep water site should represent approximately one annual cycle of sediment deposition. The low $\delta^{13} \mathrm{C}_{\text {org }}$ of $-29.4 \%$ in core top sediments is indicative of a predominantly algal source of organic matter, which is likely dominated by diatom and cyanobacteria material. Although $\delta^{13} \mathrm{C}_{\text {org }}$ is consistent between trap and sediment cores, $\mathrm{C} / \mathrm{N}$ and $\mathrm{HI}$ show a change to higher (7.6 to 9.6) and lower (390 to 316) values, respectively, in core top samples. $\mathrm{C} / \mathrm{N}$ may potentially vary due to differential loss rates between $\mathrm{C}$ and $\mathrm{N}$ in the sediment as part of early diagenetic processes where $\mathrm{N}$ is lost at a higher rate than $\mathrm{C}$ (Gälman et al., 2008). While this may be a factor in producing the difference in $\mathrm{C} / \mathrm{N}$ observed at Rostherne Mere, the distribution of $n$-alkanes in the uppermost sediments indicates a source of higher $\mathrm{C} / \mathrm{N}$ organic material is more likely the cause for divergence between the water column and sediment record. The alkane distribution for core top samples shows a distinct peak at $n \mathrm{C}_{17}$, relating to a predominant component of algal material. Yet there is a clear secondary maxima centred on $n \mathrm{C}_{29}$, suggesting the presence of longer-chained hydrocarbons and delivery of non-algal material to the sediments, which would also contribute to lower HI values in core tops (Talbot and Livingstone, 1989).

Although the distinctive alkane maxima at $n \mathrm{C}_{17}$ in trap sediments confirms a dominant algal signal, subsequent smaller peaks are also observed between $n \mathrm{C}_{25-33}$, concordant with the presence of longer-chained hydrocarbons in core top samples. Submerged aquatic macrophytes, mainly consisting of Callitriche at Rostherne Mere (Carvalho, 1993), show nalkane peaks between $n \mathrm{C}_{27-31}$, corresponding to the pattern found in core tops and traps, but also have major peaks at $n \mathrm{C}_{21}$ and $n \mathrm{C}_{23}$. Maxima at these chain lengths are not found in the trap or core top sediments; therefore, it is unlikely that Callitriche is one of the major contributors to the Rostherne Mere organic pool. This is still found to be the case even when post-depositional processes are considered. Although the samples subjected to degradation in both oxic and anoxic environments show a preferential loss of the shorter-chained fraction (carbon maximum shifts from $n \mathrm{C}_{23}$ to $n \mathrm{C}_{27}$ ), clear peaks are still found at $n \mathrm{C}_{21}$ and $n \mathrm{C}_{23}$. This is also the case for Typha root samples, which show dominant peaks at $n \mathrm{C}_{23}$ and $n \mathrm{C}_{25}$. The leaves and stems of Phragmites and Typha have an $n$-alkane distribution more consistent with that of trap and core top samples; however, any contribution would have to be minor given their high TOC, C/N and S2, which are significantly higher than all trap and core samples (Table 1; Figure 6). Following degradation, the distribution of $n$-alkanes from plant samples remains fairly constant (Figure 3); therefore, no overall signal change would be expected due to early diagenetic processes. Although diagenetic changes do not appear to influence the $n$ alkane distribution in samples, total $n$-alkane concentrations are observed to change between 
fresh and degraded samples, indicating that a component of the plant material was lost. The process of selective degradation appears to have a more pronounced influence on bulk parameters, such as $\mathrm{C} / \mathrm{N}$ and S2 (Figure 6). Although, even after degradation, the geochemical separation between autochthonous and allochthonous organic constituents remains distinct, and traditional interpretations of material source differentiation are still valid (Meyers and Teranes, 2001). One exception is Callitriche, whose data indicate degraded samples assimilate $\delta^{13} \mathrm{C}_{\mathrm{org}}, \mathrm{C} / \mathrm{N}$, and $\mathrm{S} 2$ values that are congruous with cores and traps (Figure 6). Nonetheless, Callitriche most likely provides a negligible contribution to the sediment architecture given its $n$-alkane distribution.

A further source of organic material to the lake and its sediments is from soil. The transfer of soil organic matter from the catchment to the lake is most likely dependent on inflow from Rostherne Brook, accounting for $\sim 75 \%$ of water input, with secondary input via surface runoff from surrounding land through small streams and drainage ditches (Carvalho, 1993; Carvalho et al., 1995). The $n$-alkane composition of soils from the inflow river channel shows peak concentrations at $n \mathrm{C}_{29}$ with lesser peaks at $n \mathrm{C}_{27}, n \mathrm{C}_{31}$, and $n \mathrm{C}_{25}$. This distribution is broadly similar to the distribution associated with woodland and grassland soils and is representative of the distribution observed across longer-chained homologues in trap and core top sediments (Figures 4 and 5). Although woodland soil has high $\mathrm{C} / \mathrm{N}$ and $\delta^{13} \mathrm{C}_{\text {org }}$, soils from inflow and grassland catchment localities have a relatively low organic matter content (low TOC and S2; Figure 6) and have $\delta^{13} \mathrm{C}_{\text {org }}$ and $\mathrm{C} / \mathrm{N}$ similar to core tops (Table 1). These values suggest that these soils may supply the main component of the lake's allochthonous sediment. Further validation of organic matter provenance can be ascertained using the S2 pyrograms (Figure 3). Fresh plant samples have a unimodal distribution characterised by peaks at low pyrolysis temperatures $\left(330-375^{\circ} \mathrm{C}\right)$. Trap and core top samples, however, show a bimodal distribution with maximum hydrocarbon abundance around $360{ }^{\circ} \mathrm{C}$ and a secondary, broader peak of lower hydrocarbon abundance extending between $\sim 400$ and $500{ }^{\circ} \mathrm{C}$. The only samples to be characterised by a strong bimodal distribution are those from soils, most likely due to the incorporation of organic matter with high thermal stability, such as lignin and tannin (Carrie et al., 2012; Newell et al., 2016). These results suggest that Rostherne surface sediments are characterised by both low and high thermal stability components, indicating that input of organic materials is dominated by the autochthonous production of algal matter with a contribution from soils. Marginal vegetation belts most likely have a restricted influence on sediments. Given that the trap collections between April and September are significantly dominated by algal-derived organic matter (Figure 3), the higher thermal stability components found in core top sediments are most likely transferred during winter months. This transfer may account for a proportion of the geochemical offset between the trap and core sediments.

\subsection{Organic geochemistry of the sediment record}

The two cores from Rostherne Mere were retrieved in shallow (RM-S1; oxic) and deep (RMD4; anoxic) water areas of the lake and can therefore provide information on spatial differences in sedimentation across the basin and the influence of redox conditions on sediment proxies. Considering the different sedimentation rates and, therefore, sampling resolution for each core, the overall profile of all proxies is largely consistent, both in terms of the magnitude of observed changes and in absolute values between the two coring 
locations (Figures 4 and 5). Core RM-D4, in comparison to core RM-S1, shows lower average TOC, C/N, and HI between 1955 and present day (given the common chronological ${ }^{210} \mathrm{~Pb}$ tie point; Table 1), which may suggest that a greater proportion of the deeper water sediments comprise a higher concentration of lithogenic material with a detrital origin. This interpretation is corroborated by similar average $\delta^{13} \mathrm{C}_{\text {org }}$ and OI for RM-S1 and RM-D4 (around $-28.6 \%$ and 178, respectively). Rostherne Mere sediments therefore indicate that proxy values are generally consistent across both shallow and deep water and oxic and anoxic depositional environments. Sediment focussing (differentially winnowing finer organic matter from the shallower to deeper lake areas) does not materially influence the interpretation of the records.

The surface sediments of Rostherne Mere are shown to consist predominantly of organic matter dominated by autochthonous components; however, shifts in proxy values are observed in deeper horizons (Figures 4 and 5), which is also indicated by previous investigations (Cardoso et al., 1983; Prartono and Wolff, 1998). Lower $\delta^{13} \mathrm{C}_{\text {org }}$ and $\mathrm{C} / \mathrm{N}$ and higher TOC and HI in sediments from the upper parts of the cores are consistent with a productive, eutrophic lake system and an algal-dominated source of organic matter. Towards the lower part of the cores, however, higher $\delta^{13} \mathrm{C}_{\text {org }}$ and $\mathrm{C} / \mathrm{N}$ and lower TOC and HI may reflect either a shift in the balance of organic material being supplied to the lake from different sources, where allochthonous material was more dominant in past years, or potentially could be the result of diagenetic modification to the organic matter over time. The change from higher to lower $\delta^{13} \mathrm{C}_{\text {org }}$ through both cores may also be partly attributed to the lowering of $\delta^{13} \mathrm{C}$ atmospheric $\mathrm{CO}_{2}$ due to anthropogenic burning of fossil fuels (the Suess effect; Keeling, 1979).

Post-depositional diagenesis has been shown to have no significant impact on the $\delta^{13} \mathrm{C}$ of algal organic matter (Hodell and Schelske, 1998; Meyers and Lallier-Verges, 1999).

Although changes in the molecular composition of vascular plant material are observed, $\delta^{13} \mathrm{C}$ is also consistent between fresh and buried allochthonous materials (Meyers et al., 1995). As with $\delta^{13} \mathrm{C}, \mathrm{C} / \mathrm{N}$ values are considered to be typically representative of the original material, where changes are not of a sufficient magnitude to override larger-scale source determinations (Meyers and Ishiwatari, 1993). A relative change in $\mathrm{C} / \mathrm{N}$ has been shown to be driven by the selective loss of $\mathrm{N}$ over $\mathrm{C}$ at a rate of $\sim 1: 1.5$, leading to increasing $\mathrm{C} / \mathrm{N}$ through time (Gälman et al., 2008). The rate of diagenetic loss of both $\mathrm{C}$ and $\mathrm{N}$, however, is highest within 5 years after deposition (20\% and 30\%, respectively) and reduces considerably over time with a maximal $\mathrm{C} / \mathrm{N}$ difference of +2 between recent and degraded sediments (Gälman et al., 2008). The observed $\delta^{13} \mathrm{C}_{\text {org }}$ and $\mathrm{C} / \mathrm{N}$ change of approximately $+1.6 \%$ and +4 , respectively, from the upper to lower sediments of cores RM-S1 and RM-D4 (1955-present) therefore suggests that the balance between autochthonous and allochthonous components is shifting downcore and recording palaeoenvironmental change, rather than primarily reflecting the influence of diagenetic processes.

To assess further the change in organic constituents, S2 pyrograms (the main constituent of HI) and $n$-alkane distributions are plotted in Figures 4 and 5. Pyrograms from the uppermost sediments of cores RM-S1 and RM-D4 show a bimodal distribution across the S2 temperature range of 300 to $600{ }^{\circ} \mathrm{C}$. Shallower sediments, as previously discussed, are characterised by a distinct peak at a pyrolysis temperature of around $360{ }^{\circ} \mathrm{C}(\mathrm{S} 2 \mathrm{a})$ and a second, less pronounced peak (S2b) at the higher pyrolysis temperature of $460{ }^{\circ} \mathrm{C}$. A strong 
S2a peak form indicates the presence of organics with low to moderate thermal stability, such as those derived from lipid cell wall materials, and therefore implies a signal driven by algalderived organic matter (Carrie et al., 2012). This interpretation is confirmed by the presence of short-chained hydrocarbons in both cores (Figures 4 and 5), in particular the peak observed at $n \mathrm{C}_{17}$, which is commonly associated with algal-dominated sediments (Clark and Blumer, 1971). In both RM-S1 and RM-D4, there is a clear change from the upper to mid-core depths. Mid-core sediments in both cores show a marginally reduced hydrocarbon abundance in contrast to upper sediments and a bimodal distribution characterised by a stronger S2b peak at $460{ }^{\circ} \mathrm{C}$. In the lowermost sediments of both cores, there is a considerable reduction in hydrocarbon abundance compared to upper- and mid-level sediments, and the S2 peak structure becomes broader and less defined between S2a and S2b, particularly for core RMD4. A shift to an S2b-dominated pyrogram form suggests a lower relative abundance of algal matter in sediments and a greater contribution of higher thermal stability elements (Carrie et al., 2012). These characteristics imply that these sediments contain a component of terrestrial material, which is validated by the reduction in short-chained hydrocarbons in $n$-alkane profiles and a shift to a long-chained-dominated assemblage between $n \mathrm{C}_{27}$ and $n \mathrm{C}_{33}$.

This shift to an assemblage dominated by long-chain hydrocarbons is illustrated in the $n$ alkane ratios ACL and TAR (Figures 4 and 5). Higher ACL and TAR in sediments from the lower sections of both cores indicate a terrestrial dominance of organic matter content (Bourbonniere and Meyers, 1996; Bush and McInerney, 2013) and confirm that a greater proportion of long-chained hydrocarbons are present. Contrastingly, the upper core is characterised by lower ACL and TAR, indicating an up-core change from a relatively low abundance to a higher content of lake-derived organic matter. This shift, together with a parallel rise and strong covariance between TOC and HI ( $\mathrm{R}>0.8$ for both cores), suggests that the signal is driven by an increasing contribution of autochthonous organic matter rather than diminishing terrestrial inputs (Meyers, 2003; Steinmann et al., 2003). A change to environmental conditions favouring increased aquatic productivity in the upper core is further supported by a transition to lower $\mathrm{C} / \mathrm{N}$, indicating a greater contribution from non-vascular algal organic matter (Meyers and Teranes, 2001). In addition to lower $\mathrm{C} / \mathrm{N}$, increasing MinC through the cores implies greater endogenic carbonate precipitation, most probably in response to increased phytoplankton activity and photosynthetic uptake of dissolved $\mathrm{CO}_{2}$, thereby driving calcium carbonate supersaturation in the water column (Ito, 2001; Leng and Marshall, 2004; Scott, 2014).

\subsection{Impact of anthropogenic environmental change}

At the base of core RM-S1, relatively high TOC (>10\%) and moderate HI (>230) suggest that Rostherne Mere was a productive lake and had likely developed enriched conditions before the end of the $19^{\text {th }}$ century (Figure 7). This interpretation is supported by an extended history of human activity and catchment modification in the local area, including agriculture, habitation of surrounding villages, and infrastructure development. Cultural eutrophication was most likely strengthened following a period of forest clearance and agricultural development after ca. 600 BP (Nelms, 1984). Long-term monitoring and sedimentary diatom analysis confirm that enriched conditions have existed since at least 1912 (Pearsall, 1923; Radbourne, 2018). TOC is relatively consistent at the base of core RM-S1 up to ca. 1953, after which there is a substantial shift to higher TOC and HI, suggesting greater organic 
matter accumulation (Figure 7). This shift is also observed in $\delta^{13} \mathrm{C}_{\text {org }}$ and $\mathrm{C} / \mathrm{N}$, which are stable until ca. 1953, followed by a marked trend towards the lower values of present day. Lower but consistent TOC and higher $\mathrm{C} / \mathrm{N}$ and $\delta^{13} \mathrm{Corg}_{\text {org }}$ at the base of the core correspond to lower accumulation rates of planktonic diatoms and organic carbon burial before the $19^{\text {th }}$ century until the mid-20 $0^{\text {th }}$ century (Nelms, 1984; Radbourne et al., 2017).These values reflect reduced productivity compared to more recent conditions in Rostherne Mere.

The comparatively rapid shift of the mid-1950s observed in core RM-S1 is not seen in the corresponding interval of core RM-D4, which has a lowermost ${ }^{210} \mathrm{~Pb}$ date of $1955 \pm 8$ years (Figure 2). A reduction in the sedimentation rate between ca. 1955 and 1964 is observed in both cores, as are the relatively stable sedimentation rates between ca. 1964 and present day. This agreement suggests the dating on the two cores is comparable and well-resolved after 1955. The rapid TOC increase in core RM-S1 between 1953 and 1955 may correspond to a similar increase between 1940 and 1947 in core RM-D4. The TOC increase is substantiated by similar trends in $\mathrm{C} / \mathrm{N}, \delta^{13} \mathrm{Corg}_{\text {org }}$, and $\mathrm{HI}$ through the same interval (Figure 7). The base of core RM-S1 has larger chronological errors associated with the ${ }^{210} \mathrm{~Pb}$ chronology (Figure 2), and a high sedimentation rate in core RM-S1 through this zone implies the potential for sediment slumping and/or an erosional event, which may explain the discrepancy between the cores. The part of RM-S1 dated to the early 20th century (ca. 1919-1933) is characterised by low TOC $(\sim 11 \%)$. A distinct shift to higher TOC values is observed in the part of the core from the mid-20th century, where TOC is $\sim 14 \%$." A large perturbation in TOC is also observed in RM-D4 around 1935 (Figure 7). This pronounced change in organic carbon content is most likely related to the construction of local sewage treatment works in 1935 that discharged effluent upstream of Rostherne Mere until the effluent was diverted in 1991 (Carvalho et al., 1995). Nutrient budgeting has shown that the effluent comprised around $70 \%$ of the external nutrient load from the Rostherne Brook inflow (Moss et al., 1997; Radbourne, 2018), which suggests a considerable increase in nutrient (P) loading following the construction of the treatment plants.

In RM-S1 and RM-D4, $\delta^{13} \mathrm{C}_{\text {org }}$ remains moderately consistent at $-28 \%$ until ca. 1960 and then starts to progressively decrease. This decline is also observed as a trend to higher TOC and $\mathrm{HI}$ and lower $\mathrm{C} / \mathrm{N}$ (Figure 7). These changes are broadly concurrent with an abrupt transformation of the lake's cyanobacteria assemblage that took place around 1958 (Livingstone, 1979), as well as diatom replacement by species characteristic of very eutrophic waters and a reduction in the accumulation of non-planktonic diatoms (Nelms, 1984; Radbourne, 2018). A primary cause of this change may be related to a transition from phytoplankton being N-limited to a state where populations were instead controlled by light availability (Reynolds and Bellinger, 1992). Other work suggested that this change ultimately was driven by an increase in the use of synthetic agricultural fertilisers, leading to further nutrient enrichment in the lake (Reynolds, 1979). Many lakes around the UK and Europe similarly provide evidence for eutrophication starting in the mid- $19^{\text {th }}$ century, often with a more distinct phase since ca. 1950 (Battarbee et al., 2011; Bennion et al., 2012; Anderson et al., 2014; Heathcote et al., 2015). This change in TOC and $\delta^{13} \mathrm{C}_{\text {org }}$ is gradual and of a lesser magnitude compared to the initial effects of sewage effluent input in the early $20^{\text {th }}$ century, and is instead most likely associated with external nutrient loading from agricultural runoff (up to 27\%; Moss et al., 1997). This period is followed by overall higher TOC and decreasing 
$\mathrm{C} / \mathrm{N}$ and $\delta^{13} \mathrm{C}_{\text {org }}$, which is associated with an increasing sedimentation rate until ca. 1980 (Figure 7).

In the early 1980s, an increase in TOC and an overall rapid decrease in $\delta^{13} \mathrm{C}_{\text {org }}$ and $\mathrm{C} / \mathrm{N}$ are observed in both cores (Figure 7). A higher rate of decreasing $\delta^{13} \mathrm{C}_{\text {org }}$ and $\mathrm{C} / \mathrm{N}$, and higher TOC suggest sediments contain an increasing proportion of autochthonous organic matter. This change is consistent with lower TAR and ACL (Figure 4) and is simultaneous with an abrupt increase in the rate of organic carbon burial after ca. 1980 (approximately $+15 \%$; Figure 7; Radbourne et al., 2017). These proxy changes likely reflect a period of peak eutrophication, perhaps due to a further increase in nutrient loading from the sewage treatment works given the similarity to the intensification of eutrophication following the construction of the sewage treatment works in the 1930s. Originally, the treatment works served a population of 550 people; however, by the 1980s, they had become overloaded due to local housing development (Moss et al., 2005). By 1990, the sewage treatment works served a population of 3,350 people (Carvalho et al., 1995).

Following the transition to lower $\delta^{13} \mathrm{C}_{\text {org }}$ from ca. 1980 , a change to relatively stable $\delta^{13} \mathrm{C}_{\text {org }}$ is observed between ca. 1994 and present day in parallel with a continued $\mathrm{C} / \mathrm{N}$ decrease in both cores (Figure 7). This broad-scale change follows the closure of the sewage treatment works in 1991; however, the shift to low and stable $\delta^{13} \mathrm{C}_{\text {org }}$ in both cores post-dates the diversion of effluent by several years. Although external nutrient loading fell dramatically following diversion (the phosphorus load in Rostherne Brook reduced by $\sim 78 \%$ ), total outputs from the lake remained constant (Carvalho et al., 1995). In contrast to upstream Little Mere where there was a distinct and immediate decline in total $\mathrm{P}$ following sewage diversion, substantial internal nutrient loading in Rostherne Mere resulted in increased lake concentrations of total P between 1992 and 1993 (Carvalho et al., 1995). Only a limited decline in concentration was observed over the next decade (Moss et al., 2005). Since ca. 1994, stable $\delta^{13} \mathrm{C}_{\text {org }}$ around $-29.5 \%$ are consistent with modern trap sediments, implying that although external nutrient loading has been greatly reduced, internal nutrient loading has likely resulted in a slow remediation of hypereutrophic conditions and restricted ecological recovery.

\section{Conclusions}

- The dominant source of organic matter to the sediments of Rostherne Mere is derived from autochthonous material, which is based on maxima in n-alkanes at $n \mathrm{C}_{17}$ and overall low $\delta^{13} \mathrm{C}_{\text {org }}$ and $\mathrm{C} / \mathrm{N}$ and high $\mathrm{HI}$ values in trap and core top data. Catchment soils also contribute to the sediments and are most likely transferred during winter months, as suggested by differences in $\mathrm{HI}$ and $\mathrm{C} / \mathrm{N}$ between traps and core tops and the presence of longer-chained hydrocarbons in core tops.

- Conventional interpretations of organic matter provenance remain valid after sinking and burial because changes in the values of geochemical proxy data are minor. Early 
diagenetic processes in core sediments do not overprint the signal of changing palaeoenvironmental conditions, which is important for setting recent anthropogenicinduced changes in a historical context. Sediment focussing and differential redox conditions across the lake basin also do not exert considerable influence over the general profile of excursions observed in multi-proxy records.

- Autochthonous organic matter production in the lake increased over the $20^{\text {th }}$ century, and the transition to hypereutrophic conditions took place at a variable rate. This transition was principally dependent on the delivery of point-source sewage effluent and enhanced phosphorus loading following the construction of sewage treatment works in mid-1930s, the introduction of synthetic fertilisers in the late 1950s, and population growth through the 1980s. In recent years, remediation has reduced the influence of external nutrient loading; however, internal nutrient loading has slowed ecological recovery.

- Overall, this study shows how sedimentary organic matter can sensitively record recent eutrophication processes in lakes. It highlights the efficacy of using a combination of geochemical techniques, in particular $\delta^{13} \mathrm{C}_{\text {org }}$, Rock-Eval, and $n$ alkane biomarkers, and the need integrate modern end-member calibrations and lacustrine sediment cores to better understand the timing and scale of environmental change through the Anthropocene.

\section{Acknowledgements}

This work was carried out during the $\mathrm{PhD}$ of JHL which was funded by the British Geological Survey University Funding Initiative (BUFI). The authors thank Natural England for access to Rostherne Mere, are grateful for fieldwork assistance from Daniel Scott, and would like to thank two anonymous reviewers whose comments improved the manuscript. This paper is published with permission of the Executive Director of the British Geological Survey (NERC). 


\section{References}

Anderson, N.J., Bennion, H., Lotter, A.F., 2014. Lake eutrophication and its implications for organic carbon sequestration in Europe. Glob Chang Biol 20, 2741-2751.

Appleby, P.G., Richardson, N., Nolan, P.J., 1992. Self-absorption corrections for well-type germanium detectors. Nuclear Instruments and Methods in Physics Research Section B: Beam Interactions with Materials and Atoms 71, 228-233.

Banks, J.W., 1970. Observations on the fish population of Rostherne Mere, Cheshire. Field Studies 3, 357-379.

Battarbee, R.W., Morley, D., Bennion, H., Simpson, G.L., Hughes, M., Bauere, V., 2011. A palaeolimnological meta-database for assessing the ecological status of lakes. Journal of Paleolimnology 45, 405-414.

Bennion, H., Carvalho, L., Sayer, C.D., Simpson, G.L., Wischnewski, J., 2012. Identifying from recent sediment records the effects of nutrients and climate on diatom dynamics in Loch Leven. Freshwater Biology 57, 2015-2029.

Bourbonniere, R.A., Meyers, P.A., 1996. Sedimentary geolipid records of historical changes in the watersheds and productivities of Lakes Ontario and Erie. Limnology and Oceanography 41, 352-359.

Brooks, P.W., Eglinton, G., Gaskell, S.J., McHugh, D.J., Maxwell, J.R., Philp, R.P., 1976. Lipids of Recent sediments, Part I: Straight-chain hydrocarbons and carboxylic acids of some temperate lacustrine and sub-tropical lagoonal/tidal flat sediments. Chemical Geology 18, 2138.

Bush, R.T., McInerney, F.A., 2013. Leaf wax n-alkane distributions in and across modern plants: Implications for paleoecology and chemotaxonomy. Geochimica et Cosmochimica Acta 117, 161-179.

Cardoso, J.N., Gaskell, S.J., Quirk, M.M., Eglinton, G., 1983. Hydrocarbon and fatty acid distributions in Rostherne lake sediment (England). Chemical Geology 38, 107-128.

Carrie, J., Sanei, H., Stern, G., 2012. Standardisation of Rock-Eval pyrolysis for the analysis of recent sediments and soils. Organic Geochemistry 46, 38-53.

Carvalho, L., Beklioglu, M., Moss, B., 1995. Changes in a deep lake following sewage diversion - a challenge to the orthodoxy of external phosphorus control as a restoration strategy? Freshwater Biology 34, 399-410.

Carvalho, L.R., 1993. Experimental limnology on four Cheshire Meres. University of Liverpool.

Castañeda, I.S., Schouten, S., 2011. A review of molecular organic proxies for examining modern and ancient lacustrine environments. Quaternary Science Reviews 30, 2851-2891.

Clark, R.C., Blumer, M., 1971. Distribution of n-paraffins in marine organisms and sediments. Limnology and Oceanography $12,79-87$. 
Cohen, A.S., 2003. Paleolimnology: The History and Evolution of Lake Systems. Oxford University Press, Oxford.

Cranwell, P.A., Eglinton, G., Robinson, N., 1987. Lipids of aquatic organisms as potential contributors to lacustrine sediments II. Organic Geochemistry 11, 513-527.

Davison, W., Woof, C., 1984. A study of the cycling of manganese and other elements in a seasonally anoxic lake, Rostherne Mere, U.K. Water Research 18, 727-734.

Eglinton, G., Hamilton, R.J., 1967. Leaf Epicuticular Waxes. Science 156, 1322-1335.

Espitalie, J., Laporte, J.L., Madec, M., Marquis, F., Leplat, P., Paulet, J., Boutefeu, A., 1977. Rapid Method for Source Rock Characterization and for Determination of Their Petroleum Potential and Degree of Evolution. Rev Inst Fr Pet 32, 23-42.

Ficken, K.J., Li, B., Swain, D.L., Eglinton, G., 2000. An n-alkane proxy for the sedimentary input of submerged/floating freshwater aquatic macrophytes. Organic Geochemistry 31, 745749.

Gälman, V., Rydberg, J., de-Luna, S.S., Bindler, R., Renberg, I., 2008. Carbon and nitrogen loss rates during aging of lake sediment: Changes over 27 years studied in varved lake sediment. Limnology and Oceanography 53, 1076-1082.

Gaskell, S.J., Eglinton, G., 1976. Sterols of a contemporary lacustrine sediment. Geochimica et Cosmochimica Acta 40, 1221-1228.

Heathcote, A.J., Anderson, N.J., Prairie, Y.T., Engstrom, D.R., del Giorgio, P.A., 2015. Large increases in carbon burial in northern lakes during the Anthropocene. Nat Commun 6, 10016.

Hodell, D.A., Schelske, C.L., 1998. Production, sedimentation, and isotopic composition of organic matter in Lake Ontario. Limnology and Oceanography 43, 200-214.

Holtvoeth, J., Rushworth, D., Copsey, H., Imeri, A., Cara, M., Vogel, H., Wagner, T., Wolff, G.A., 2016. Improved end-member characterisation of modern organic matter pools in the Ohrid Basin (Albania, Macedonia) and evaluation of new palaeoenvironmental proxies. Biogeosciences 13, 795-816.

Ito, E., 2001. Application Of Stable Isotope Techniquesto Inorganic And Biogenic Carbonates, in: Last, W., Smol, J. (Eds.), Tracking Environmental Change Using Lake Sediments. Springer Netherlands, pp. 351-371.

Keeling, C.D., 1979. The Suess effect: ${ }^{13}$ Carbon- ${ }^{14}$ Carbon interrelations. Environment International 2, 229-300.

Khan, N.S., Horton, B.P., McKee, K.L., Jerolmack, D., Falcini, F., Enache, M.D., Vane, C.H., 2013. Tracking sedimentation from the historic A.D. 2011 Mississippi River flood in the deltaic wetlands of Louisiana, USA. Geology 41, 391-394.

Krivtsov, V., Sigee, D., Bellinger, E., 2001. A one-year study of the Rostherne Mere ecosystem: seasonal dynamics of water chemistry, plankton, internal nutrient release, and implications for long-term trophic status and overall functioning of the lake. Hydrological Processes 15, 1489-1506. 
Lacey, J.H., Francke, A., Leng, M.J., Vane, C.H., Wagner, B., 2015. A high-resolution Late Glacial to Holocene record of environmental change in the Mediterranean from Lake Ohrid (Macedonia/Albania). Int J Earth Sci 104, 1623-1638.

Langford, F.F., Blanc-Valleron, M.M., 1990. Interpreting Rock- Eval Pyrolisis data using graphs of pyrolizable hydrocarbons vs. total organic carbon. AAPG Bulletin 74, 799-804.

Leng, M.J., Marshall, J.D., 2004. Palaeoclimate interpretation of stable isotope data from lake sediment archives. Quaternary Science Reviews 23, 811-831.

Livingstone, D., 1979. Algal remains in recent lake sediments, Department of Geology. University of Leicester.

Livingstone, D., Reynolds, C.S., 1981. Algal sedimentation in relation to phytoplankton periodicity in Rostherne Mere. British Phycological Journal 16, 195-206.

Meyers, P.A., 1997. Organic geochemical proxies of paleoceanographic, paleolimnologic, and paleoclimatic processes. Organic Geochemistry 27, 213-250.

Meyers, P.A., 2003. Applications of organic geochemistry to paleolimnological reconstructions: a summary of examples from the Laurentian Great Lakes. Organic Geochemistry 34, 261-289.

Meyers, P.A., Ishiwatari, R., 1993. Lacustrine organic geochemistryman overview of indicators of organic matter sources and diagenesis in lake sediments. Organic Geochemistry 20, 867-900.

Meyers, P.A., Lallier-Verges, E., 1999. Lacustrine sedimentary organic matter records of Late Quaternary paleoclimates. Journal of Paleolimnology 21, 345-372.

Meyers, P.A., Leenheer, M.J., Bourbonniere, R.A., 1995. Diagenesis of Vascular Plant Organic Matter Components during Burial in Lake Sediments. Aquatic Geochemistry 1, 3552.

Meyers, P.A., Teranes, J.L., 2001. Sediment Organic Matter, in: Last, W.M., Smol, J.P. (Eds.), Tracking Environmental Change Using Lake Sediments. Springer Netherlands, pp. 239-269.

Moss, B., Barker, T.O.M., Stephen, D., Williams, A.E., Balayla, D.J., Beklioglu, M., Carvalho, L., 2005. Consequences of reduced nutrient loading on a lake system in a lowland catchment: deviations from the norm? Freshwater Biology 50, 1687-1705.

Moss, B., Beklioglu, M., Carvalho, L., Kilinc, S., McGowan, S., Stephen, D., 1997. Vertically-challenged limnology; contrasts between deep and shallow lakes. Hydrobiologia $342,257-267$.

Natural England, 2012. Macrophyte survey of Rostherne Mere, Unpublished report, p. 22.

Nelms, R.J., 1984. Palaeolimnological studies of Rostherne Mere (Cheshire) and Ellesmere (Shropshire). PhD Thesis, Liverpool Polytechnic. 
Newell, A.J., Vane, C.H., Sorensen, J.P.R., Moss-Hayes, V., Gooddy, D.C., 2016. Long-term Holocene groundwater fluctuations in a chalk catchment: evidence from Rock-Eval pyrolysis of riparian peats. Hydrological Processes 30, 4556-4567.

Pearsall, W.H., 1923. The phytoplankton of Rostherne Mere. Memoirs and Proceedings of the Manchester Literature \& Philosophical Society 67, 45-55.

Peters, K.E., Walters, C.C., Moldowan, J.M., 2005. The Biomarker Guide: Biomarkers and Isotopes in Petroleum Exploration and Earth History. Cambridge University Press, New York.

Prartono, T., Wolff, G.A., 1998. Organic geochemistry of lacustrine sediments: a record of the changing trophic status of Rostherne Mere, U.K. Organic Geochemistry 28, 729-747.

Radbourne, A.D., Ryves, D.B., Anderson, N.J., Scott, D.R., 2017. The historical dependency of organic carbon burial efficiency. Limnology and Oceanography 62, 1480-1497.

Radbourne, A.D., 2018. Disentangling the impacts of nutrient enrichment and climatic forcing as key drivers of change at Rostherne Mere. PhD Thesis, Loughborough University.

Renberg, I., 1991. The HON-Kajak sediment corer Journal of Paleolimnology 6, 167-170.

Reynolds, C.S., 1978. Notes on the phytoplankton periodicity of Rostherne Mere, Cheshire, 1967-1977. British Phycological Journal 13, 329-335.

Reynolds, C.S., 1979. The Limnology of the Eutrophic Meres of the Shropshire-Cheshire Plain: A Review. Field Studies Journal 5, 93-173.

Reynolds, C.S., Bellinger, E.G., 1992. Patterns of abundance and dominance of the phytoplankton of Rostherne Mere, England: evidence from an 18-year data set. Aquatic Sciences 54, 10-36.

Scott, D.R., 2014. Carbon fixation, flux and burial efficiency in two contrasting eutrophic lakes in the UK (Rostherne Mere \& Tatton Mere). PhD Thesis, Loughborough University.

Sebag, D., Debret, M., M'Voubou, M., Obame, R.M., Ngomanda, A., Oslisly, R., Bentaleb, I., Disnar, J.R., Giresse, P., 2013. Coupled Rock-Eval pyrolysis and spectrophotometry for lacustrine sedimentary dynamics: Application for West Central African rainforests (Kamalete and Nguene lakes, Gabon). The Holocene 23, 1173-1183.

Steinmann, P., Adatte, T., Lambert, P., 2003. Recent changes in sedimentary organic matter from Lake Neuchâtel (Switzerland) as traced by Rock-Eval pyrolysis. Eclogae Geologicae Helvetiae 1, 109-116.

Talbot, M.R., Livingstone, D.A., 1989. Hydrogen Index and Carbon Isotopes of Lacustrine Organic-Matter as Lake Level Indicators. Palaeogeogr Palaeocl 70, 121-137.

Woof, C., Wall, T., 1984. The morphometry of Rostherne Mere, Cheshire.

Yang, H., Turner, S., 2013. Radiometric dating for recent lake sediments on the Tibetan Plateau. Hydrobiologia 713, 73-86.

Zocatelli, R., Turcq, B., Boussafir, M., Cordeiro, R.C., Disnar, J.R., Costa, R.L., Sifeddine, A., Albuquerque, A.L.S., Bernardes, M.C., Jacob, J., 2012. Late Holocene 
paleoenvironmental changes in Northeast Brazil recorded by organic matter in lacustrine sediments of Lake Boqueirão. Palaeogeography, Palaeoclimatology, Palaeoecology 363-364, 127-134. 


\section{Figure captions}

Figure 1: A) Location of Rostherne Mere, Little Mere, Mere Mere, and the Rostherne and Mere sewage treatment works (STW), and B) Map of Rostherne Mere with bathymetric data (in meters; Scott, 2014), showing the coring locations of RM-S1 (N53'21'28.7', W2 23'22.1”) and RM-D4 (N53²1'12.6”, W2²3'19.4”; Map data: Google, Bluesky).

Figure 2: Radiometric chronology versus depth for cores RM-S1 and RM-D4, showing the CRS model ${ }^{210} \mathrm{~Pb}$ dates (black squares) with respective error bars and sedimentation rate (grey circles). Fallout radionuclide concentrations versus depth are also shown for total ${ }^{210} \mathrm{~Pb}$, supported ${ }^{210} \mathrm{~Pb}$, unsupported ${ }^{210} \mathrm{~Pb},{ }^{137} \mathrm{Cs}$, and ${ }^{241} \mathrm{Am}$. A zone of high sedimentation rate in RM-S1 implies the potential for sediment slumping, which is highlighted by the horizontal grey bar.

Figure 3: Chain-length distributions of $n$-alkane biomarkers (black bars) and Rock-Eval S2 pyrograms (grey lines) of modern sediment traps (water depth of shallow $=8 \mathrm{~m}$, deep $=22.5$ $\mathrm{m}$ ), catchment soils (inflow/woodland/grassland), and fresh and degraded (oxic/anoxic) vegetation samples (Phragmites/Typha/Callitriche) samples. S2 pyrogram y-axis values (abundance of hydrocarbons in mg HC/g TOC) are given as integrated peak area (Hydrogen Index) in Table 1.

Figure 4: Organic geochemistry of sediment core RM-S1, showing MinC (equivalent to TIC), TOC, $\mathrm{C} / \mathrm{N}, \delta^{13} \mathrm{C}_{\mathrm{org}}$, HI, OI, ACL, $\mathrm{P}_{\mathrm{aq}}$, and TAR. ${ }^{210} \mathrm{~Pb}$ ages are shown to the right of the diagram. Grey bar marks area of high sedimentation rate. Rock-Eval S2 pyrograms are shown for three horizons (each pyrogram represent the given core depth) with $n$-alkane biomarker distributions (biomarker samples were combined from the sample depths given in the pyrograms).

Figure 5: Organic geochemistry of sediment core RM-D4, showing MinC (equivalent to TIC), TOC, $\mathrm{C} / \mathrm{N}, \delta^{13} \mathrm{C}_{\text {org }}, \mathrm{HI}, \mathrm{OI}, \mathrm{ACL}, \mathrm{P}_{\mathrm{aq}}$, and TAR. ${ }^{210} \mathrm{~Pb}$ ages are shown to the right of the diagram. Rock-Eval S2 pyrograms are shown for three horizons (each pyrogram represent the given core depth) with $n$-alkane biomarker distributions (biomarker samples were combined from the sample depths given in the pyrograms).

Figure 6: Plot of $\delta^{13} \mathrm{C}_{\text {org versus }} \mathrm{C} / \mathrm{N}$ (top) and Rock-Eval modified Van Krevelen diagram of $\mathrm{S} 2$ versus TOC (bottom) for sediment trap, vegetation, soil, and core samples. Trap sediments for June and September are split between shallow (S) and deep (D) water samples. Blue dashed boxes show typical $\delta^{13} \mathrm{C}$ and $\mathrm{C} / \mathrm{N}$ values of major sources of lacustrine algae and $\mathrm{C}_{3}$ land plant organic matter to lake sediments (Meyers and Teranes, 2001). The boundaries between organic matter types are defined as $\mathrm{HI}=700$ and $\mathrm{HI}=200$ after Langford and Blanc-Valleron (1990).

Figure 7: Comparison of TOC, $\mathrm{C} / \mathrm{N}, \delta^{13} \mathrm{C}_{\mathrm{org}}$, HI, and sedimentation rate from cores RM-S1 and RM-D4 plotted against calendar age, showing organic carbon (OC) burial rate (Radbourne et al., 2017) and the onset and cessation of sewage effluent delivery to the lake (vertical grey lines). The lowermost sedimentation rate for each core was extrapolated to the base of each sequence to provide a chronological framework for the full record.

Table 1: Geochemical, isotope, and Rock-Eval composition of modern vegetation (fresh and oxic/anoxic degraded), sediment trap, and catchment soil samples. Averages between 1955 
and present day for sediment cores RM-S1 and RM-D4 are provided. The $n$-alkane ratios ACL, $P_{a q}$, and TAR are also given for each sample. 


\section{Figure 1}
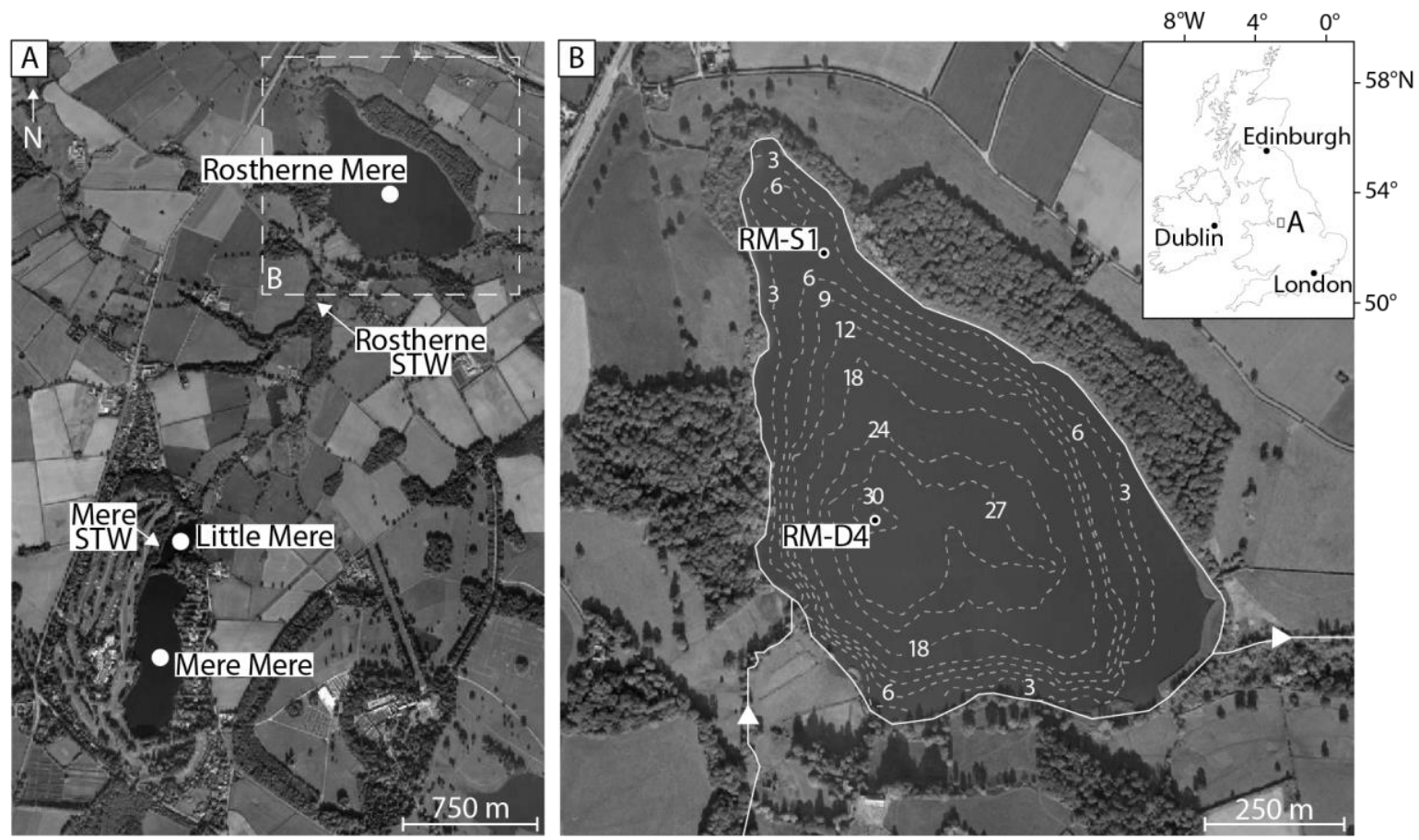
Figure 2
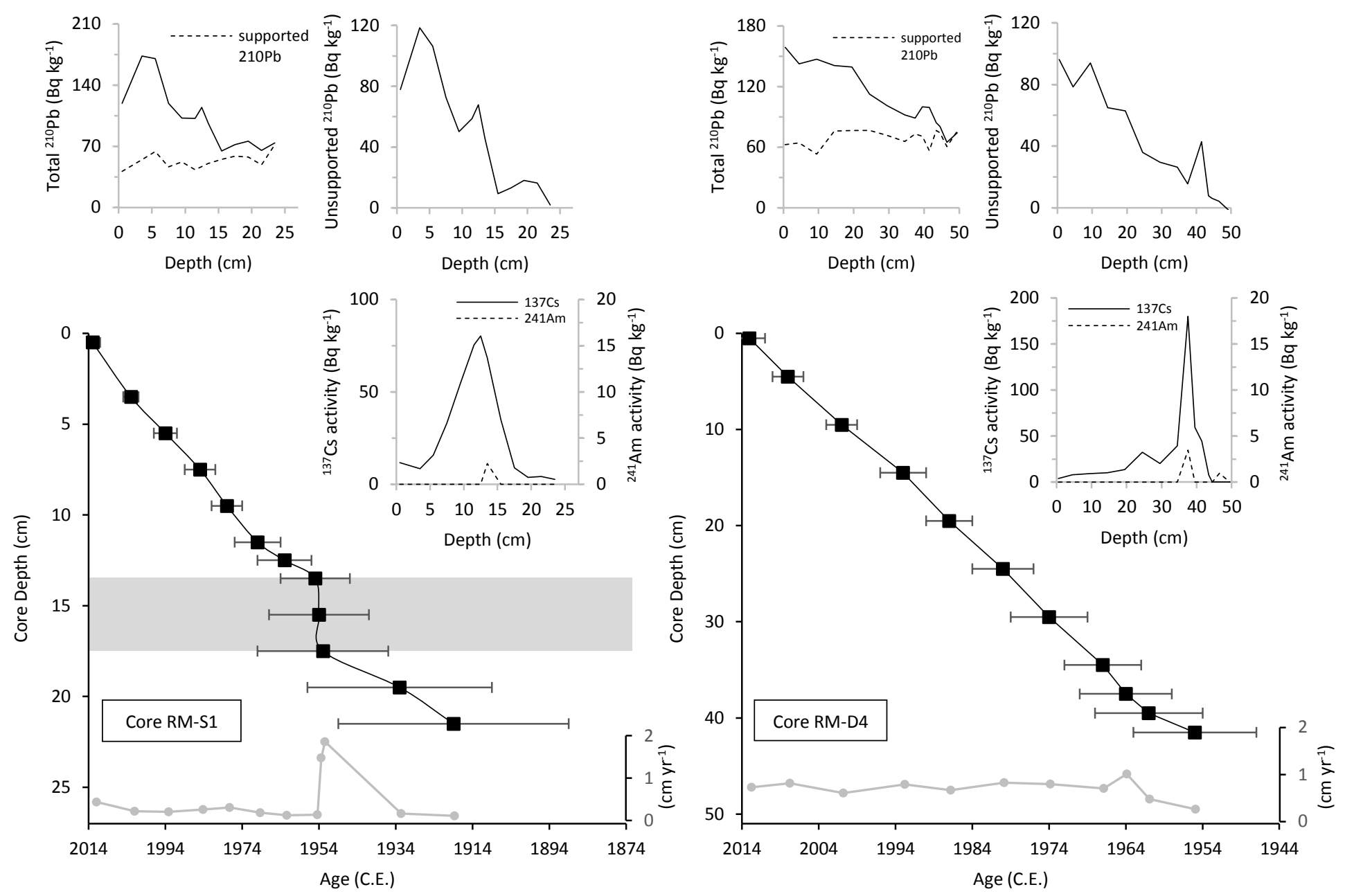
Figure 3
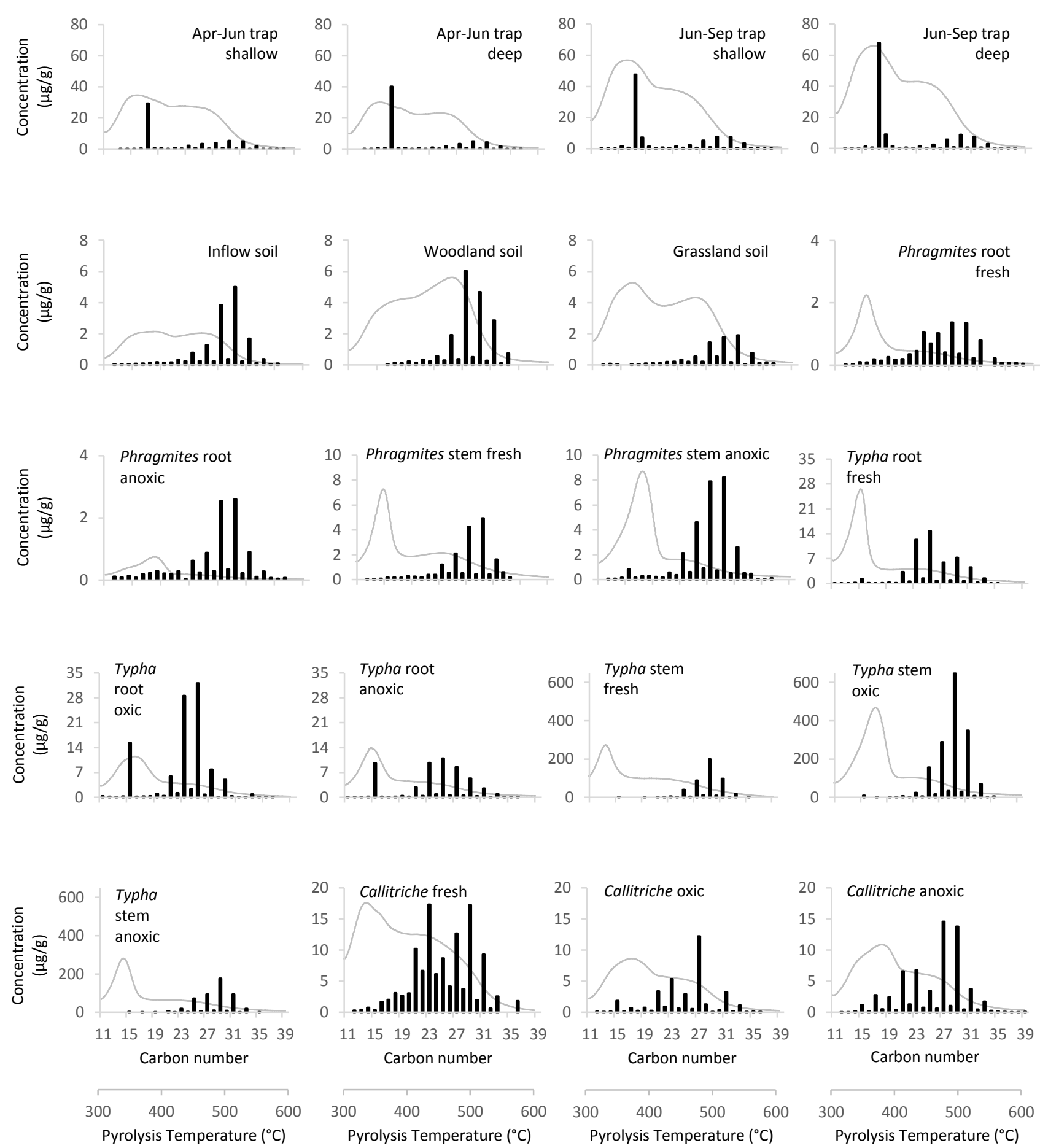
Figure 4
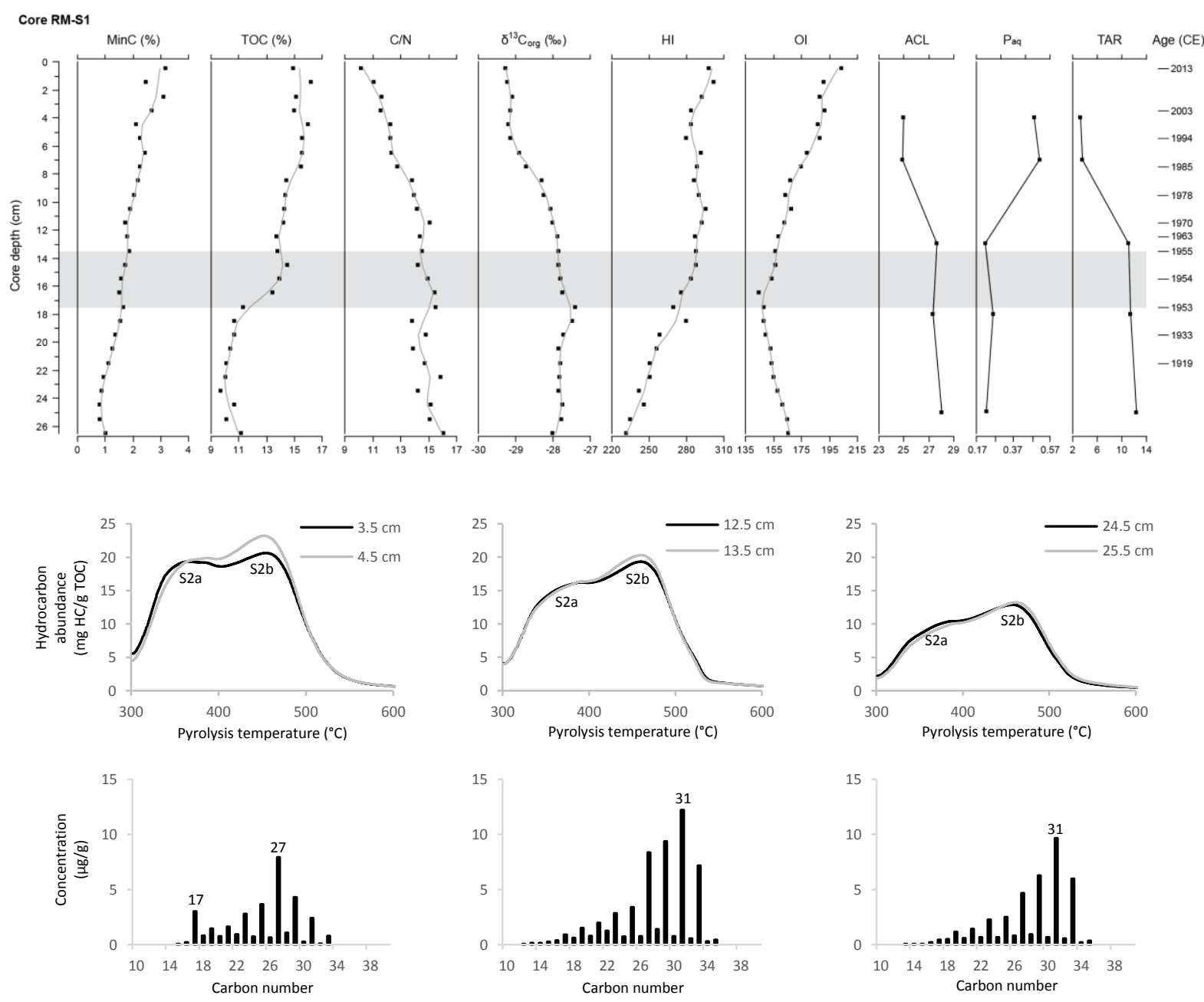
Figure 5
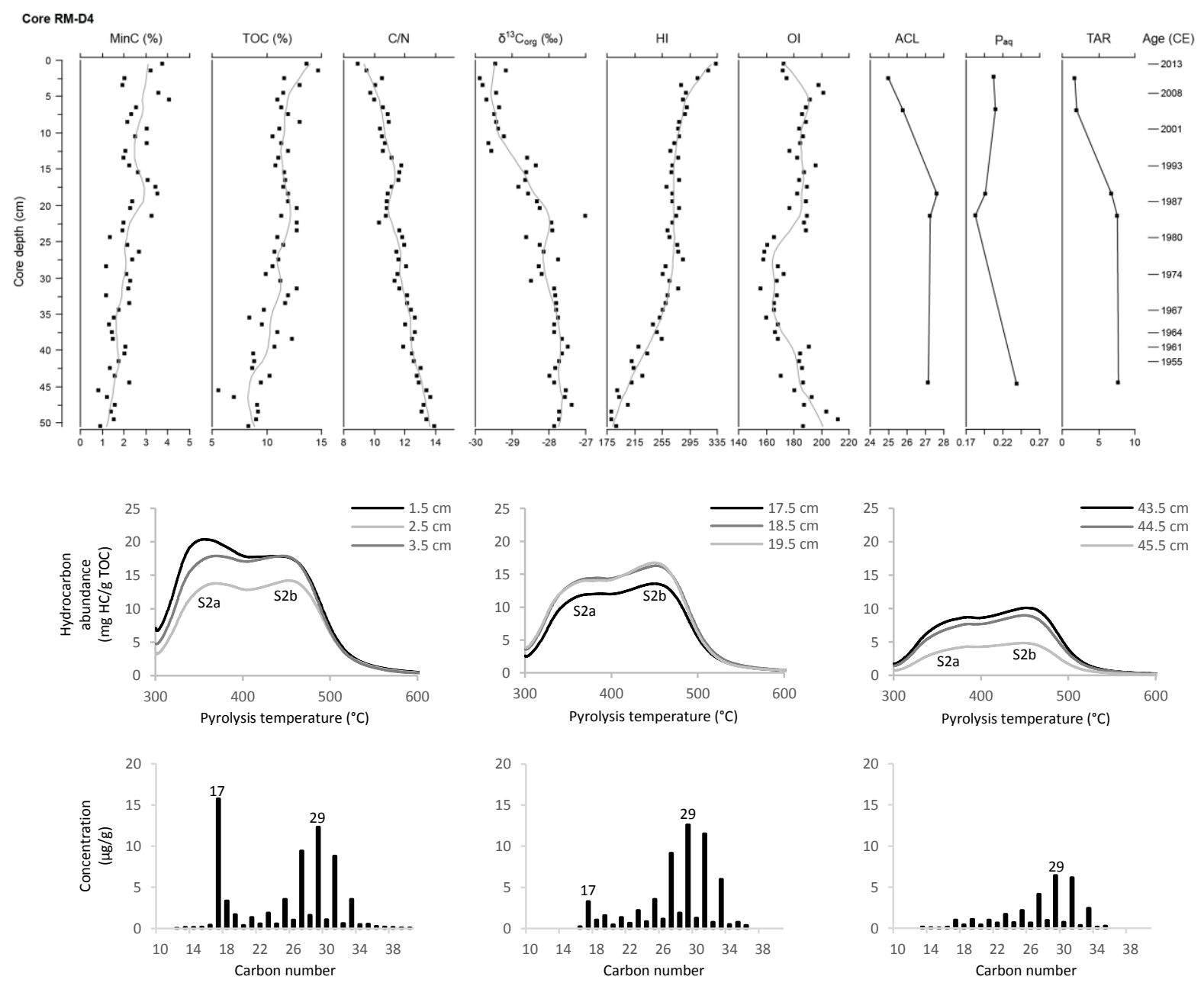


\section{Figure 6}
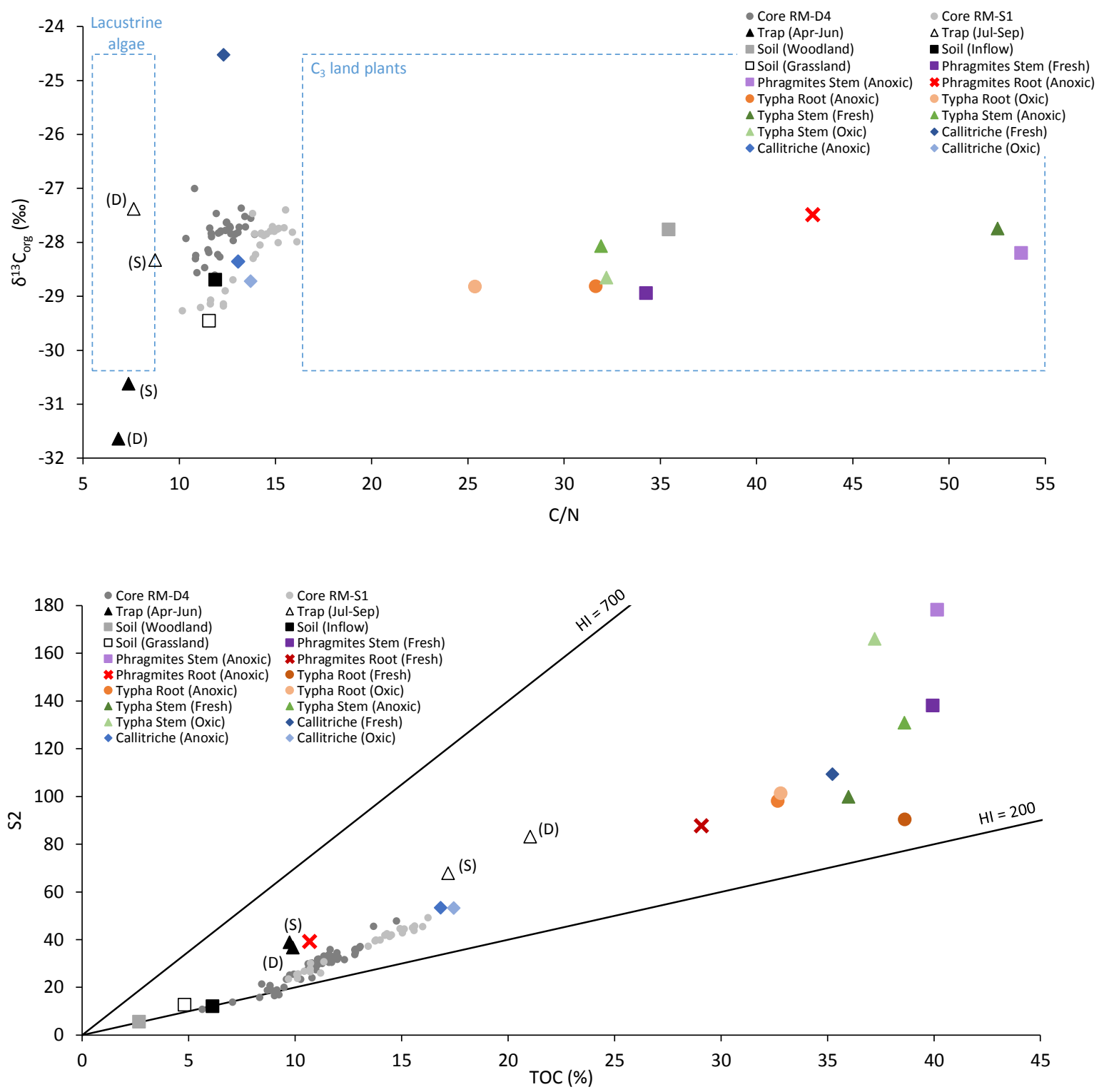
Figure 7

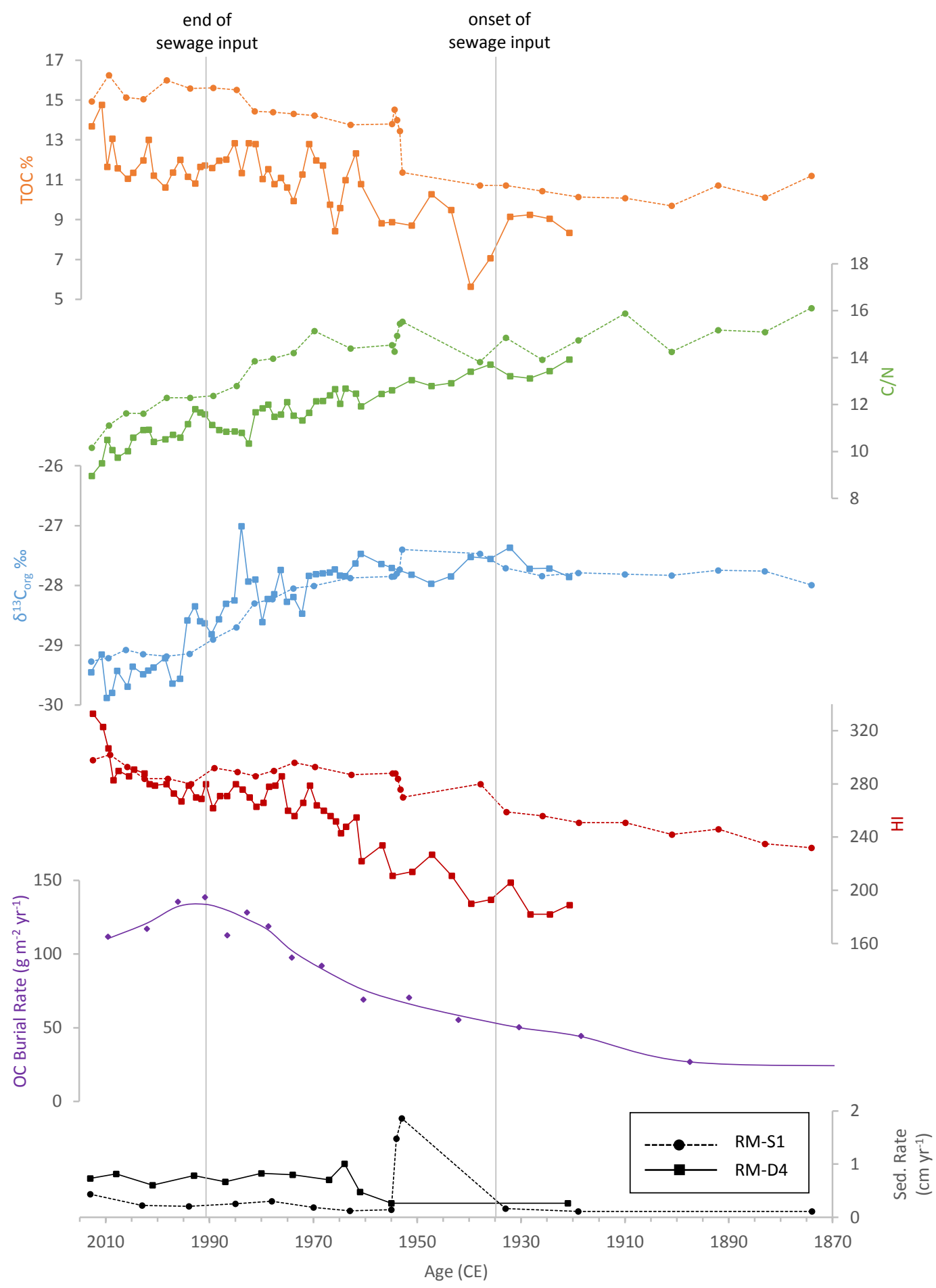


Table 1

\begin{tabular}{|c|c|c|c|c|c|c|c|c|c|c|}
\hline Sample & Fraction & MinC (\%) & TOC (\%) & $\mathrm{C} / \mathrm{N}$ & $\delta^{13} C_{\text {org }}(\% o)$ & $\mathrm{HI}$ & OI & $\mathrm{ACL}$ & $\mathbf{P}_{\mathrm{aq}}$ & TAR \\
\hline \multirow{4}{*}{ Phragmites } & Root (F) & 0.45 & 29.07 & - & -27.50 & 302 & 216 & 25.49 & 0.49 & 8.61 \\
\hline & $\operatorname{Root}(A)$ & 0.59 & 10.68 & 42.92 & -27.48 & 367 & 177 & 26.16 & 0.30 & 11.49 \\
\hline & Stem (F) & 0.60 & 39.94 & 34.25 & -28.94 & 346 & 239 & 26.60 & 0.34 & 17.90 \\
\hline & Stem (A) & 1.02 & 40.15 & 53.73 & -28.19 & 444 & 160 & 26.54 & 0.38 & 13.78 \\
\hline \multirow{6}{*}{ Typha } & Root (F) & 0.82 & 38.62 & - & -27.69 & 234 & 323 & 25.43 & 0.70 & 10.62 \\
\hline & $\operatorname{Root}(A)$ & 1.08 & 32.66 & 31.63 & -28.81 & 300 & 243 & 23.67 & 0.72 & 1.61 \\
\hline & Root (O) & 1.00 & 32.80 & 25.36 & -28.82 & 309 & 255 & 22.90 & 0.92 & 0.77 \\
\hline & Stem (F) & 1.24 & 35.98 & 52.51 & -27.74 & 277 & 305 & 28.73 & 0.13 & 335.14 \\
\hline & Stem (A) & 1.47 & 38.61 & 31.91 & -28.07 & 339 & 242 & 28.09 & 0.25 & 75.21 \\
\hline & Stem (O) & 1.17 & 37.21 & 32.18 & -28.65 & 446 & 182 & 28.62 & 0.15 & 102.30 \\
\hline \multirow{3}{*}{ Callitriche } & Whole (F) & 1.70 & 35.23 & 12.29 & -24.52 & 310 & 357 & 25.11 & 0.49 & 7.78 \\
\hline & Whole (A) & 1.57 & 16.83 & 13.05 & -28.35 & 317 & 162 & 25.53 & 0.37 & 5.06 \\
\hline & Whole (O) & 1.26 & 17.44 & 13.70 & -28.72 & 305 & 173 & 24.97 & 0.71 & 4.76 \\
\hline \multirow{3}{*}{ Soil } & Woodland (F) & 0.30 & 2.67 & 35.42 & -27.76 & 211 & 237 & 27.55 & 0.25 & 36.83 \\
\hline & Inflow (F) & 0.81 & 6.12 & 11.86 & -28.69 & 197 & 237 & 27.16 & 0.24 & 28.55 \\
\hline & Grassland (F) & 0.28 & 4.80 & 11.53 & -29.45 & 266 & 260 & 27.98 & 0.19 & 31.18 \\
\hline \multirow{4}{*}{ Trap } & Jun $8.0 \mathrm{~m}$ & 6.45 & 9.73 & 7.37 & -30.62 & 399 & 180 & 22.04 & 0.35 & 0.48 \\
\hline & Jun 22.5 m & 5.93 & 9.89 & 6.85 & -31.65 & 371 & 219 & 20.78 & 0.23 & 0.31 \\
\hline & Sep $8.0 \mathrm{~m}$ & 3.12 & 17.18 & 8.73 & -28.33 & 394 & 159 & 21.28 & 0.20 & 0.40 \\
\hline & Sep $22.5 \mathrm{~m}$ & 3.19 & 21.04 & 7.62 & -27.38 & 395 & 168 & 20.55 & 0.20 & 0.31 \\
\hline \multirow{2}{*}{ Core } & RM-S1 ( $\bar{x})$ & 2.30 & 14.93 & 12.88 & -28.64 & 290 & 177 & 25.84 & 0.41 & 5.99 \\
\hline & RM-D4 ( $\bar{x})$ & 2.35 & 11.44 & 11.27 & -28.50 & 271 & 179 & 26.43 & 0.20 & 4.52 \\
\hline
\end{tabular}

$(F=$ fresh; $A=$ submerged in anoxic water; $O=$ submerged in oxic water; $\bar{x}=$ average 1955-2014) 